\title{
AN ECONOMIC EFFECTS OF THE FRAGMENTATION OF AGRICULTURAL LAND ON THE PRODUCTIVITY AND YIELD OF THE WHEAT CROP IN GHARBIA
}

\author{
GHONUIM, SHEHATA A.M., AZZAM A. ALI, \\ MOHAMED A. MOBARACK and MOFIDA E. KABEEL
}

Agricultural Economics Research Institute, Agricultural Research Centre; ARC/Egypt

(Manuscript received 7 November 2018)

This Research deals with the economic effects of the fragmentation of agricultural land on the productivity and yield of the wheat crop in Gharbia Governorate. This Research was limited to studying these effects on the Gemmiza 11 species in Gharbia Governorate. A sample of 140 farmers was selected, The 78 farmers each with less than 78 acres of land, the second consists of farmers with holdings of less than 2 acres per acre of 43 farmers, and the third holding category includes farmers with holdings of one acre The study aimed to evaluate these possessive categories to reach the best knowledge that achieve the highest rates of productivity and economic efficiency. A comparison was made between the three possessory categories according to the items of production costs, The results of the variance analysis showed that there was a significant difference of 0.01 among the three possessory categories in all production cost items. It was found that the variable production costs amounted to about 4492, 3655 and 3267 pounds per feddan in the first, second, In other words, production costs are reduced when moving from a small storage category to a larger storage category, due to the principle of capacity savings. By measuring the economic efficiency of the most productive elements affecting the production of the wheat crop (Gemmiza 11) in the three possessive categories, it was found to be positive and greater than the correct one for all the productive components of the production function models in the three possessive categories. By increasing the amount of these productive elements when used to the extent that they achieve economic efficiency. A study of the most important problems and obstacles faced by wheat growers in Gharbia Governorate by identifying them through the personal interview with the farmers of the sample of the field study and their survey revealed that there are many problems and obstacles such as productivity problems related to production and other marketing related to marketing. The increase in prices of fertilizers and pesticides, the rise in the prices of new varieties of crops, the decrease in the productivity of feddan and the erosion of covered agricultural banks, or Marketing problems Vtmthelt the most important of these problems in the decline in net feddan yield compared to crop competition, low price ardebs wheat, the difficulty of delivery of the crop to the concerned authorities and finally price fluctuation and control traders in the markets. 


\section{RECOMMENDATIONS}

1-Encourage Farmers to work on agricultural aggregates to overcome the problem of fragmentation of agricultural holdings and to make maximum use of agricultural serves.

2-Putting an appropriate price for wheat stalks to encourage Farmers to continue planting.

3-Overcome the problem of irrigation rationalizing the use of water by lining the canals and settling the soil with laser.

4-Activating the role of agricultural anchors in the identification of new varieties and rates of fertilizers and pesticides.

5-Facilitate the procedures for the Farmers 'delivery of their wheat crop to the concerned authorities and the quick disbursement of their dues. 


\title{
الآثار الاقتصادية لتفتت حيازة الأراضي الزراعية علي إنتاجية وعائد محصول القمح بمحافظة الغزبية الارية
}

\author{
شحاتة عبد المقصود غنيم ، عزام عبد اللطيف السيا \\ محمد عبد الستار علي مبارك ، مفيدة السيد محمد قابيل عليل علئ
}

\section{معه بحوث الاقتصاد الزراعي - مركز البحوث الزراعية}

\begin{abstract}
الـمــــــــة

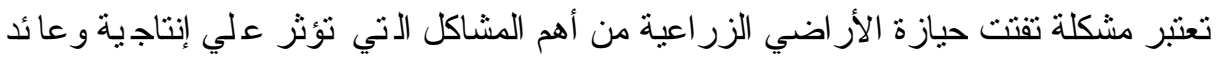

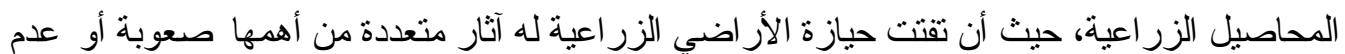

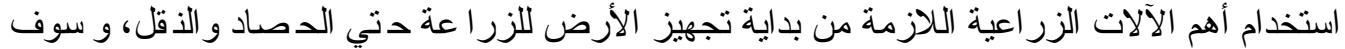

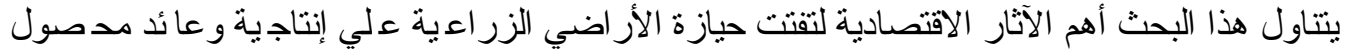

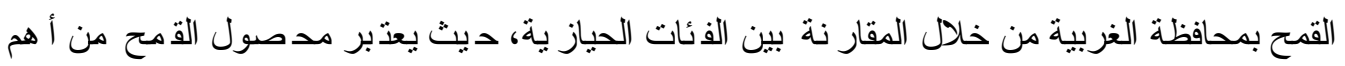

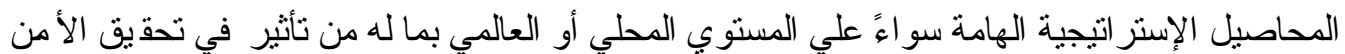

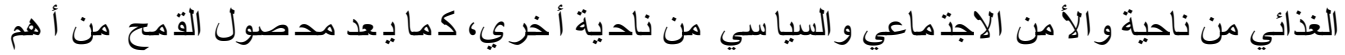

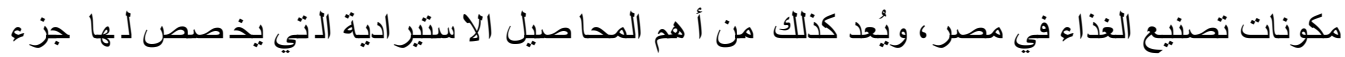
كبير من الميز انية العامة للدولة، وقد ارتفع منوسط كمية القمح المـ ستورد خلال الفترة من عند عام 1995

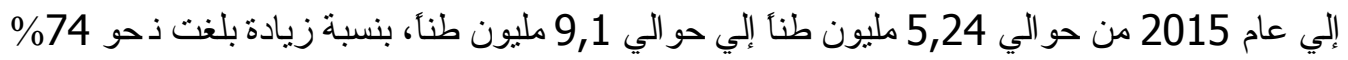
عن سنة الأساس وهي 1995 ونظر أ لأهمية هذا المحصول فقد اتخذت الدو لة مجمو عة من السيا سات

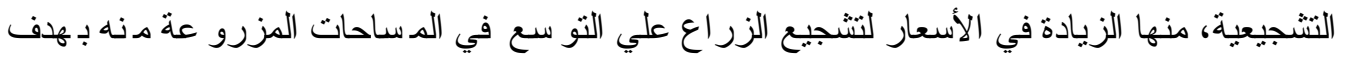

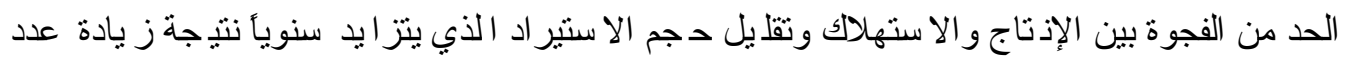

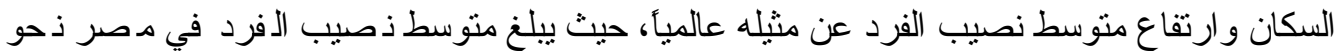
167,8 كجم/سنة، بينما يبلغ ذحو 67كجم/سنة عالميأ بز يادة دقدر بنحو 100كجم/سنة خلال الفترة

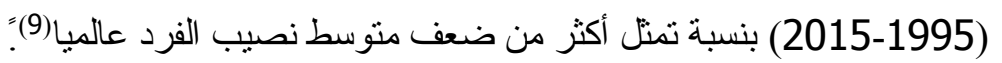
وقد بلغت المساحة المزروعة بمحصول القمح علي مستوي الجمهورية حو الي 3,57 ملايون فدان عام 2016 تعطي منوسط إنتاجية قدره نحو 2,752 طنا//فدان، وبلغ الإنتاج الكلي ذحو

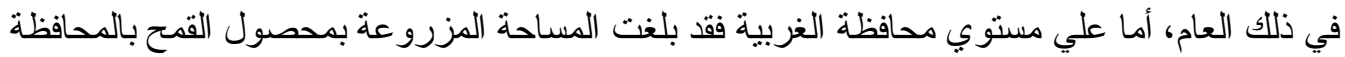
نحو 134,23 ألف فدانأ بمنوسط إنتاجية قدره 3,168 طناً / فدان (21,12 أرد بأ) وبلغ الإنتاج الكلي حو الي 425,25 ألف طنـ(8).
\end{abstract}

\section{مشكلة البحث}

يمثل محصول القمح الغذاء الرئيسي للسكان في كل من الريف و الحضر على السو اء بالا ضافة

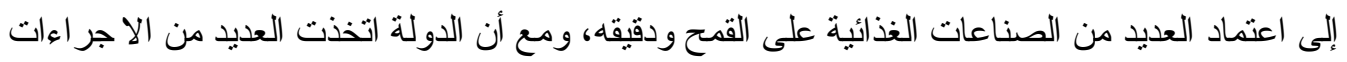

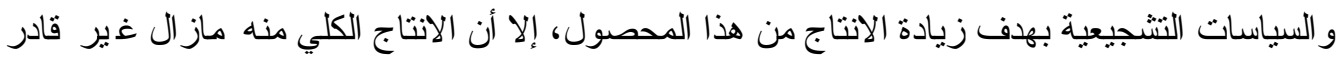
على تلبية إحتياجات الطلب المتز ايد عليه نتيجة زيادة عدد السكان، وماز الت مصر من الدول الرئئية

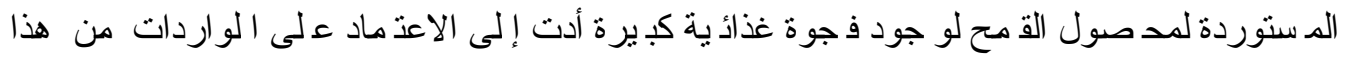
المحصول وبالتالي زيادة العبء على ميز ان المدفو عات، ولما كانت محافظة الغربية من أهم المحافظات الهات 
المنتجة لمدصول الق مح على مـ ستوي جمهور ية مصر العربة ية, وتو جد معو قات تحول دون ز يادة

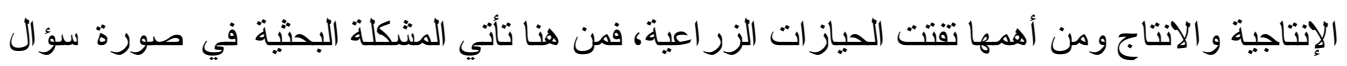

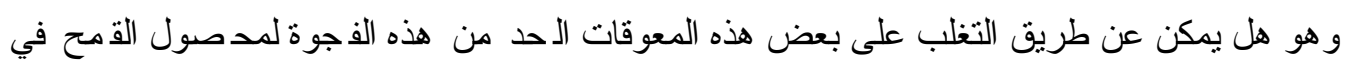
محافظة الغربية.

\section{هدف البحث}

يهدف البحث بصفة عامه إلى محاولة تقليل الفجوة الغذائية من محصول الق مح لتذفيض كمية الته

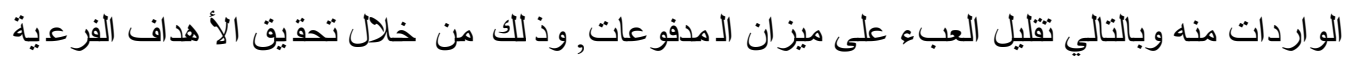
الثالية: 1- در اسة أثز تفتت حيازة الأر اضي الزر اعية على كل من التكاليف الانتاجية و الناتج و صافي العائد الفد اني. 2- التعرف على أ هم المشاكل و المعو قات التي تو اجه مزار عي مدصول الق مح بمحافظة الغربية وكيفية التغلب عليها.

$$
\text { الأسلوب البحثي }
$$

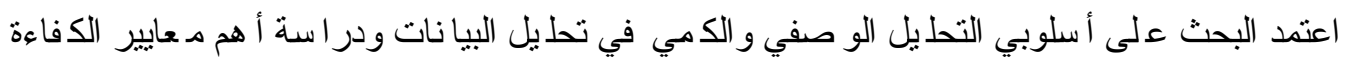

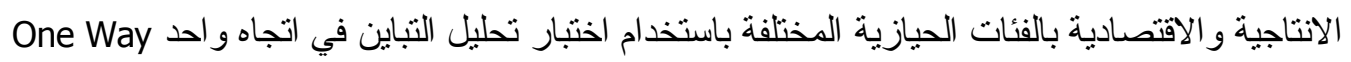

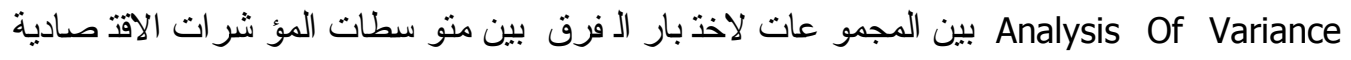

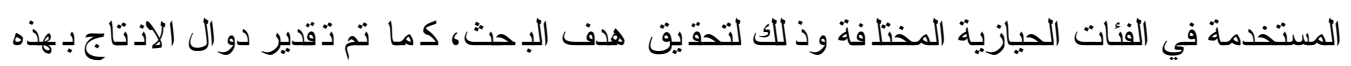

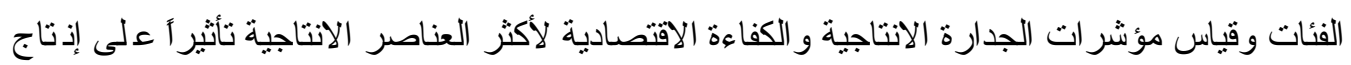
محصول القمح.

\section{مصادر البيانات}

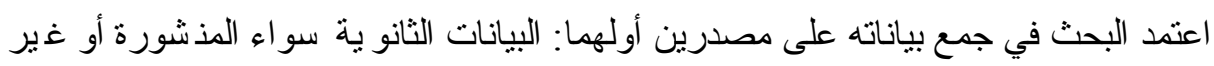

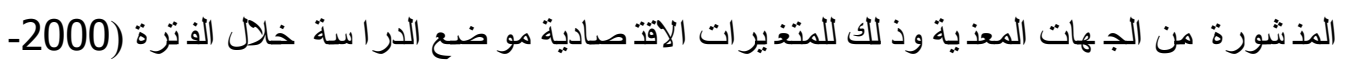

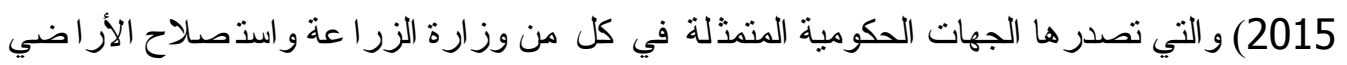

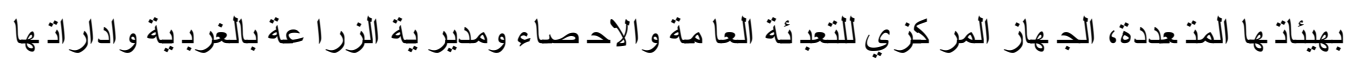

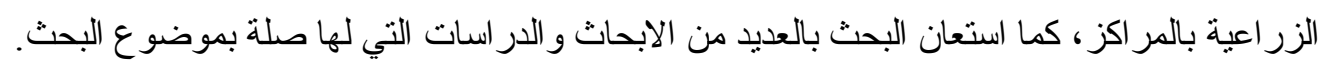

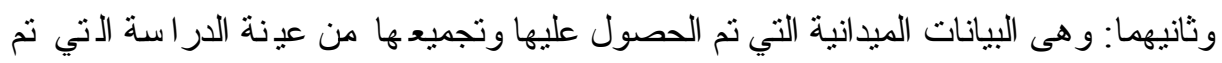

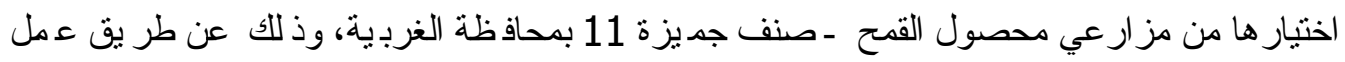

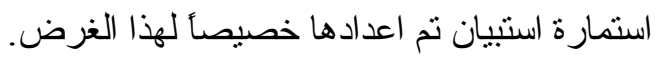

\section{اختيار عينة البحث}

تم اختيار محافظة الغربية لإجر اء هذا البحث حيث أنها من أهم المحافظات المنتهة لهن لمدصول

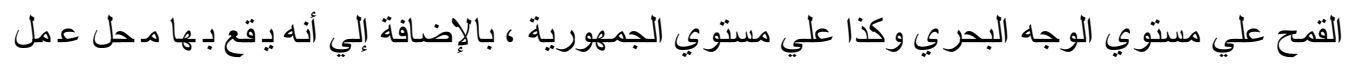

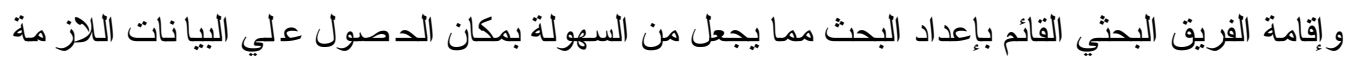

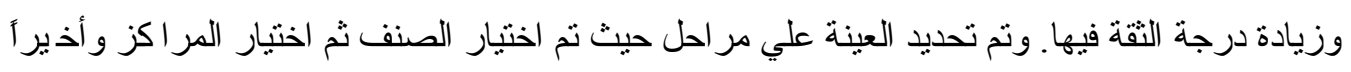

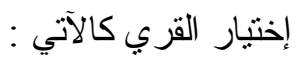

1- اختيار الصنف :

نم اختيار أكثر أصناف القمح في المساحة المزرو عة في مو سم الدراسة ويتضح من بيانات

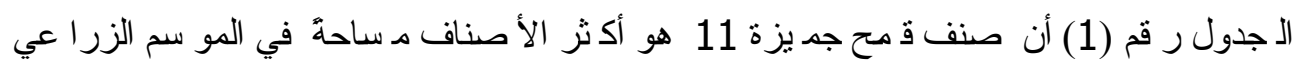


2017/2016 بمحافظة الغربية حيث بلغت مساحة هذا الصنف ذحو 54,3 ألف فدانأ تمثل ذسبة

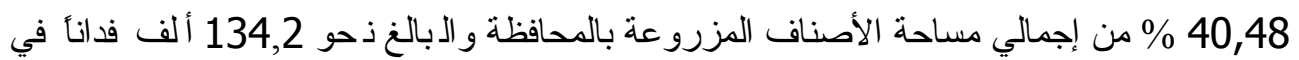
نفس الموسم. وتم تحديد واختيار صنف واحد فقط لإجر اء البحث حتي نتمكن من الدصول علي أدق الذتائج

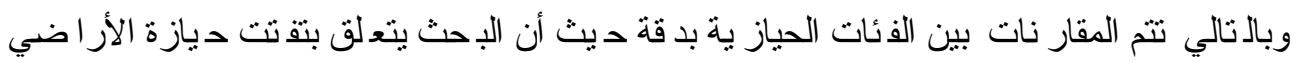
الزر اعية و أثز ذلك علي الإنتاجية و العائد الصافي. 2- 2 - 2 اختيار المر اكز :

وبعد تحديد و اختيار الصنف (صنف جميزة11) انتقلنا إلي تحديد أهم المر اكز في زر اعة هذا الصنف، حيث تم اختيار مركزي زفتي و المحلة الكبرى وفقاً للأهمية النسبية للمساحة المزروعة من فئرة

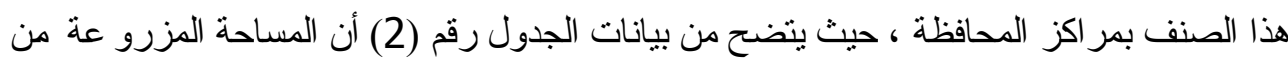

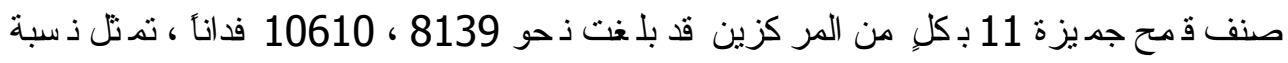

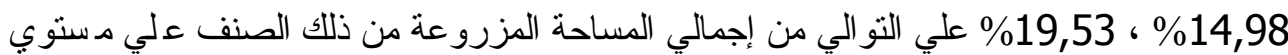
المحافظة و البالغ حو الي 54338 فـ 5488 فانأ.

جدول رقم (1) الأهمية النسبية لمساحة أصناف محصول القمح المزروعة بمر اكز محافظة الغربية في الموسم الزراعي 2016 / 2017

\begin{tabular}{|c|c|c|c|c|c|c|c|c|c|c|}
\hline \multirow{2}{*}{\multicolumn{2}{|c|}{ إجمالي مساحة الصنف بمر اكز }} & \multicolumn{8}{|c|}{ المساحة المزروعة من لصنف بمر اكز المحافظة بالفذان } & \multirow{3}{*}{ /اليبان } \\
\hline & & \multirow[b]{2}{*}{ 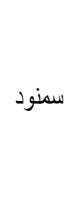 } & \multirow[b]{2}{*}{ الكبري } & \multirow[b]{2}{*}{ 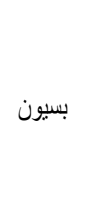 } & \multirow[b]{2}{*}{ الزيات } & \multirow[b]{2}{*}{ زفتي } & \multirow[b]{2}{*}{ السنطة } & \multirow[b]{2}{*}{ 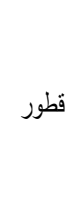 } & \multirow[b]{2}{*}{ طنطا } & \\
\hline مساحة الأصناف & فوان & & & & & & & & & \\
\hline$\% 2,47$ & 3312 & 460 & 115 & - & - & 223 & 2145 & 69 & 300 & 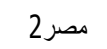 \\
\hline$\% 18,5$ & 24832 & 1637 & 10003 & 2616 & 3050 & 3002 & 776 & 1745 & 2003 & 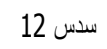 \\
\hline$\% 0,38$ & 509 & 205 & 80 & 8 & 85 & 116 & - & 8 & 7 & شندويل 1 \\
\hline$\% 14,42$ & 19360 & 1207 & 2504 & 816 & 376 & 2496 & 4427 & 2540 & 4994 & جميزة \\
\hline$\% 40,48$ & 54338 & 2575 & 10610 & 7677 & 5880 & 8139 & 6170 & 5693 & 7594 & جميزة 11 \\
\hline$\% 18,32$ & 24600 & 1504 & 9638 & 270 & 1346 & 1660 & 3494 & 4342 & 2346 & مصر 1 \\
\hline$\% 1,48$ & 1992 & 405 & 231 & 8 & - & - & - & 8 & 1340 & جميزة 12 \\
\hline$\% 2,11$ & 2834 & 286 & 328 & 104 & 646 & 672 & - & 699 & 99 & جيزة 171 \\
\hline$\% 0,67$ & 904 & 425 & 65 & 80 & - & 184 & - & - & 150 & جيزة 168 \\
\hline$\% 0,41$ & 547 & 108 & 307 & - & - & 132 & - & - & - & جميزة 10 \\
\hline$\% 0,76$ & 1016 & - & - & - & 269 & - & - & 747 & - & سذا 93 \\
\hline$\% 0,002235$ & 3 & - & - & - & - & - & - & 2 & 1 & سذا 95 \\
\hline$\% 100$ & 134247 & 8812 & 33881 & 11579 & 11652 & 16624 & 17012 & 15853 & 18834 & الإجمالي \\
\hline
\end{tabular}

المصدر : جمعت وحسبت من محافظة الغربية ـ مديرية الزراعة ـ إدارة الثئون الزراعية ـ قسم الإحصاء ، بيانات غير منشورة. 
جدول رقم (2) الأهمية النسبية للمساحة المزروعة بالقمح صنف جميزة 11 المبرة

\begin{tabular}{|c|c|c|c|c|c|c|c|c|c|c|}
\hline \multicolumn{11}{|c|}{ ز محافظة الغربية في العام الزراعي 2017/2016 } \\
\hline الإجمالي & سمنود & الكبري & بسيون & كفر الزيات & زفنتي & السنطة & قطور & طنطا & & \\
\hline 54338 & 2575 & 10610 & 7677 & 5880 & 8139 & 6170 & 5693 & 7594 & بالفاندة & المزروعة المساحة \\
\hline$\% 100$ & $\% 4,74$ & $\% 19,53$ & $\% 14,13$ & $\% 10,82$ & $\% 14,98$ & $\% 11,35$ & $\% 10,48$ & $\% 13,98$ & $\%$ & \\
\hline
\end{tabular}

حيث :

- \% تثير إلي النسبة المنوية للمساحة المزروعة من الصنف بالمركز من إجمالي المساحة المزروعة من الصنف علي مستوي

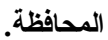

(1) المصدر : حسبت من بيانات جدول رقم

جدول رقم (3) تحديد عدد الحائزين المختارين من مزارعي القمح (صنف جميزة 11) من القري

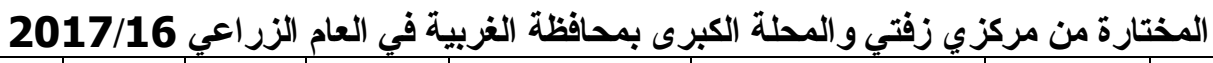

\begin{tabular}{|c|c|c|c|c|c|c|c|c|c|}
\hline \multirow{2}{*}{ الحختئزين } & \multirow{2}{*}{ الهندي الوسي } & \multirow{2}{*}{ الهنسسي } & \multirow{2}{*}{ 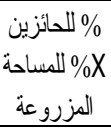 } & \multicolumn{2}{|c|}{ المساحة المزروعة } & \multicolumn{2}{|c|}{ الحائزين } & \multirow[b]{2}{*}{ القرية } & \multirow[b]{2}{*}{ مركز } \\
\hline & & & & $\%$ & بالفدان & $\%$ & عدد & & \\
\hline 30 & 21,64 & 21,52 & 463,13 & 21,59 & 311 & 21,44 & 407 & دمنهور الوحش & زفتي \\
\hline 24 & 16,70 & 16,61 & 275,98 & 20,07 & 289 & 13,71 & 261 & سنباط & \\
\hline 50 & 35,96 & 35,76 & 1278,94 & 31,94 & 460 & 40,02 & 760 & بشيش 1 & المحله \\
\hline 36 & 25,70 & 25,56 & 653,41 & 26,39 & 380 & 24,73 & 470 & بشيب 2 & الكبري \\
\hline 140 & 100 & 99,45 & & $\% 100$ & 1440 & $\% 100$ & 1898 & & \\
\hline
\end{tabular}

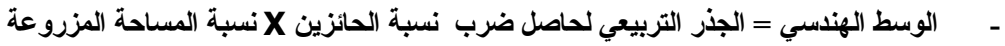

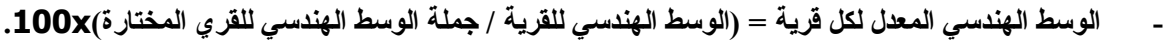

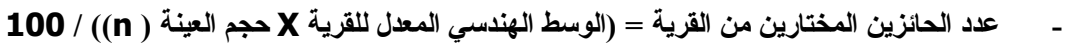

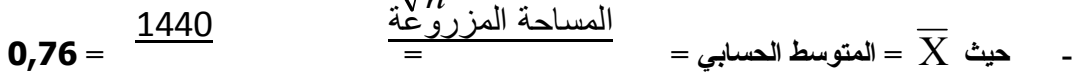

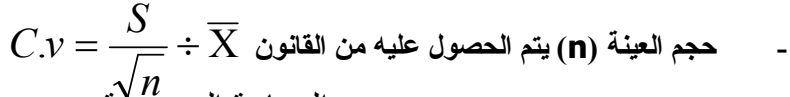

1898

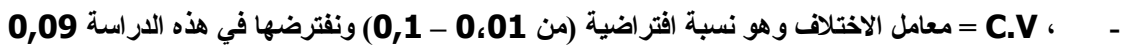

$$
\begin{aligned}
& \frac{1}{0,76} \times \frac{0,809}{\sqrt{n}}=\mathbf{0 , 0 9} \therefore \text { : } \\
& \mathbf{1 4 0}=\mathbf{n} \therefore \mathbf{1 1 , 8 2 7 5}=\quad=\frac{0,809}{0,0684}=\sqrt{n}_{0,76 \times \overline{0}, 09}
\end{aligned}
$$

ـ المصدر : جمعت وحسبت من الإدارة الزراعية بكل من مركزي زفتي والمحلة الكبري - سجلات حصر محصول القمح - بيانات غير

$$
\text { 3ـ اختيار القري : منثورة. }
$$

بعد اختيار وتحديد أهم الأصناف ثم أهم المر اكز انتقلنا إلي اختيار القري حيث تم اختيار قريتي دمنهور الوحش وسنباط من مركز زفتي ، وقريتي بشبيش 1 وبشبيش 2 من مركز المحلة الكبرى ، 
وتم اختيار هذه القري وفقأ للأهمية الذسبية للمساحة المزرو عة بالقمح صنف جميزة 11 علي مستوى قرى كل من المركزين المختارين. توزيع العينة المختارة علي القري و الفئات الحيازية بكلٍ منها:

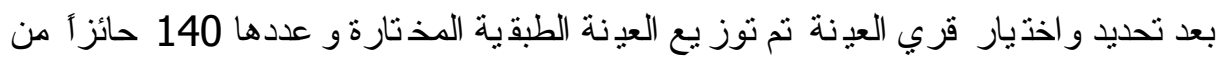

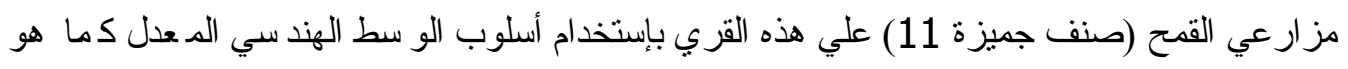

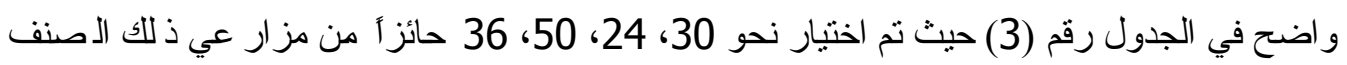

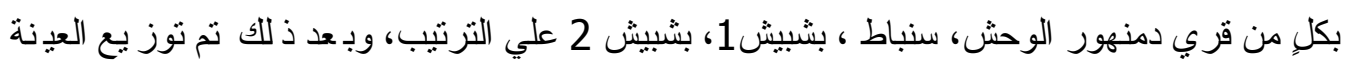

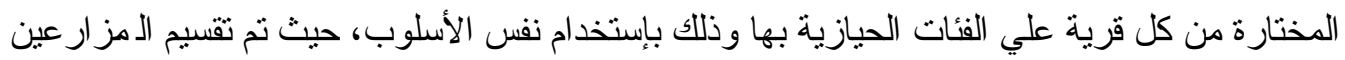

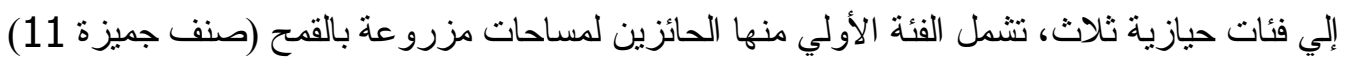

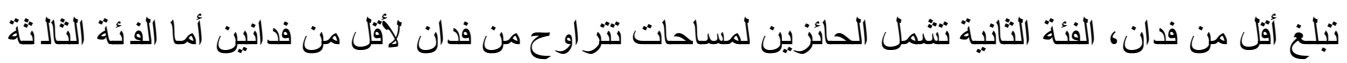

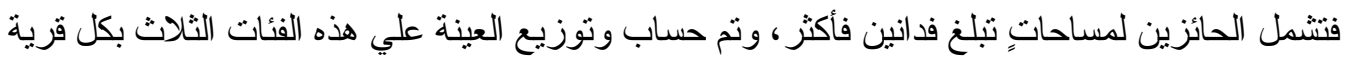

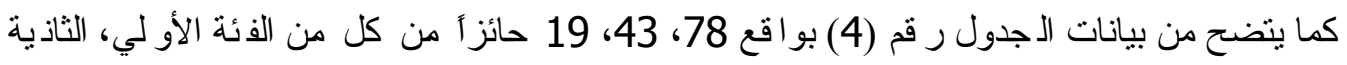

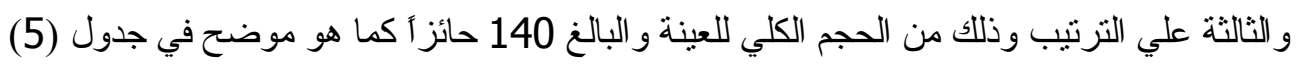

جدول رقم (4) توزيع العينة المختارة من مزارعي محصول القمح (صنف جميزة 11) علي الفئات

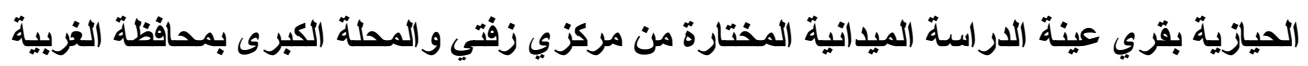

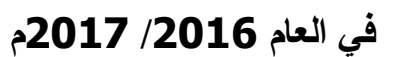

\begin{tabular}{|c|c|c|c|c|c|c|c|c|c|c|c|c|}
\hline \multirow[b]{2}{*}{ العنائزين } & \multirow[b]{2}{*}{ اللهنسي } & \multirow[b]{2}{*}{ الهنسي } & \multirow{2}{*}{ 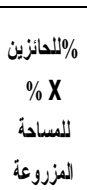 } & \multicolumn{2}{|c|}{ المسادة المززورعة } & \multicolumn{2}{|c|}{ الحائزين } & \multirow[b]{2}{*}{ العيازية } & \multirow[b]{2}{*}{ المبالقرية } & \multirow[b]{2}{*}{ بالعائزين } & & \multirow[b]{2}{*}{ 草 } \\
\hline & & & & $\%$ & فنان & $\%$ & عدل & & & & & \\
\hline 16 & 11,54 & 10,90 & 118,89 & 8,06 & 116 & 14,75 & 280 & الأولى & \multirow{3}{*}{311} & \multirow{3}{*}{407} & \multirow{3}{*}{ الودش } & \multirow{6}{*}{ 可 } \\
\hline 10 & 07,45 & 7,031 & 49,43 & 9,38 & 135 & 5,27 & 100 & الثانية & & & & \\
\hline 4 & 2,57 & 2,43 & 5,92 & 4,17 & 60 & 1,42 & 27 & الثلالة: & & & & \\
\hline 12 & 8,74 & 8,26 & 68,14 & 8,19 & 118 & 8,32 & 158 & الأولب & \multirow{3}{*}{289} & \multirow{3}{*}{261} & \multirow{3}{*}{ سنباط } & \\
\hline 9 & 6,54 & 6,18 & 38,15 & 8,33 & 120 & 4,58 & 87 & الثانية & & & & \\
\hline 3 & 1,83 & 1,74 & 2,97 & 3,54 & 51 & 0,84 & 16 & الثالثة & & & & \\
\hline 31 & 22,19 & 20,95 & 439,06 & 13,89 & 200 & 31,61 & 600 & الأولب & \multirow{3}{*}{460} & \multirow{3}{*}{760} & \multirow{3}{*}{ بُبيش 1} & \multirow{6}{*}{ 祭 } \\
\hline 12 & 8,23 & 07,77 & 60,44 & 10,42 & 150 & 5,80 & 110 & الثانية & & & & \\
\hline 7 & 4,75 & 4,483 & 20,09 & 7,64 & 110 & 2,63 & 50 & الثلألة & & & & \\
\hline 19 & 14,17 & 13,38 & 179,09 & 11,11 & 160 & 16,12 & 306 & الأولب & \multirow{3}{*}{380} & \multirow{3}{*}{470} & \multirow{3}{*}{ بُبيسش 2} & \\
\hline 12 & 8,61 & 8,13 & 66,096 & 9,72 & 140 & 6,80 & 129 & الثانية & & & & \\
\hline 5 & 3,39 & 3,20 & 10,23 & 5,56 & 80 & 1,84 & 35 & الثلالةّة & & & & \\
\hline 140 & 100 & 94,44 & & 100 & 1440 & 100 & 1898 & & 1440 & 1898 & لإبمالب & \\
\hline
\end{tabular}

حيث : الوسط الهنسسي للفئة الحيازية = الجذر التربيعي لحاصل ضرب نسبة الحائزين X نسبة المساحة المزروعة

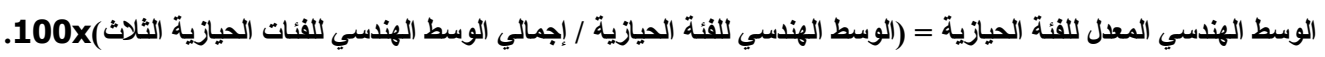
عدد الحائزين المختارين في الفئة الحيازية = (الوسط الهندسي المعدل للفئة الحيازية X حجم العينة (n)) / 100 (n) 100

المصدر : حسبت من بيانات الجدول رقم (3).

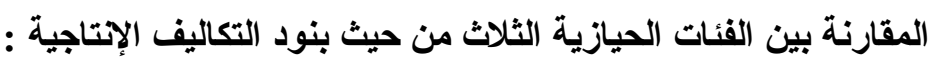

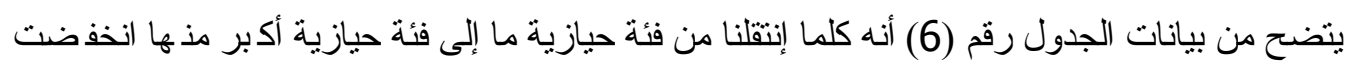

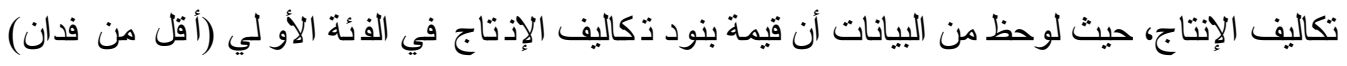

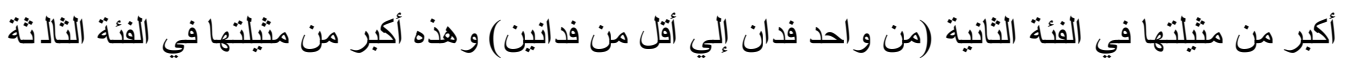


(من فدانين فأكثر) )، فيتضح من بيا نات الجدول ر قم (6) أن ذكاليف العمل البشري لافدان بل خت ذحو

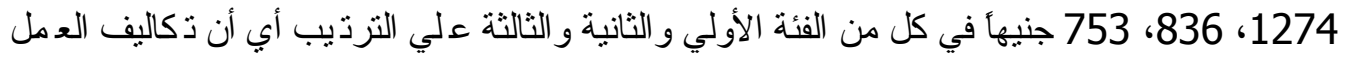

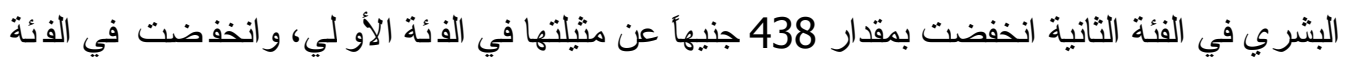
الثالثة عن مثنلتها في الفئة الثانية بمقدار 83 جنيهاء، وتثير نتائج تحليل التباين إلي أن الفروق بين الفئات

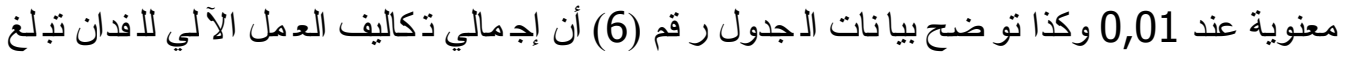

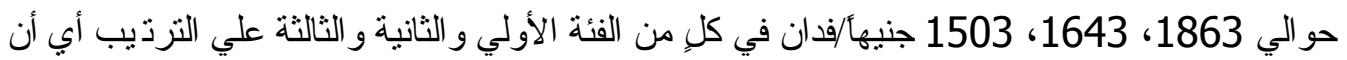

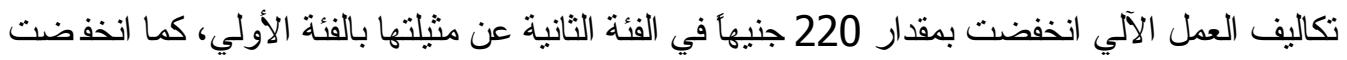
بمقدار 140 جنيها في الفئة الثالثة عن مثيلتها في الفئة الثانية، وتثثير نتائج تحليل التباين إلي أن الـفروق

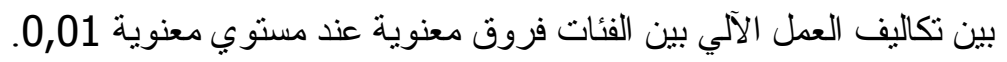

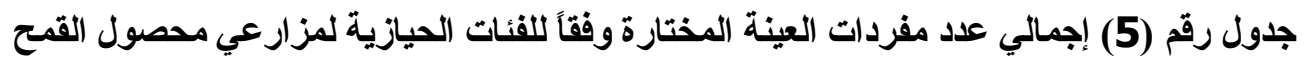

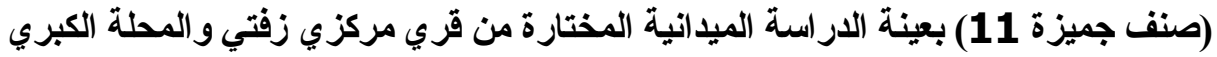

بمحافظة الغربية عام 2017/2016 بنايه

\begin{tabular}{|c|c|c|c|c|}
\hline الإجمالي & الفئة الحيازية الثالثة & 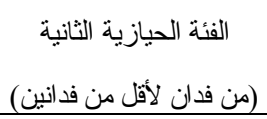 & 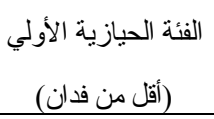 & القرية للفئة الحيازية \\
\hline 30 & 4 & 10 & 16 & دمنهور الوحش \\
\hline 24 & 3 & 9 & 12 & سنباط \\
\hline 50 & 7 & 12 & 31 & بشبيش 1 \\
\hline 36 & 5 & 12 & 19 & بشبيش 2 \\
\hline 140 & 19 & 43 & 78 & الإجمالي \\
\hline$\% 100$ & $\% 13,6$ & $\% 30,7$ & $\% 55,7$ & \% من إجمالى العينة \\
\hline
\end{tabular}

(4) المصدر : بيانات الجدول رقم

ويتضح أيضاً من بيانات الجدول رقم (6) أن إجمالي تكاليف العمل الزر اعي لافدان (الب شري

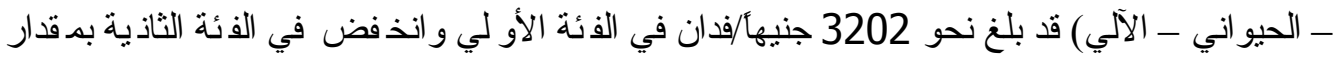

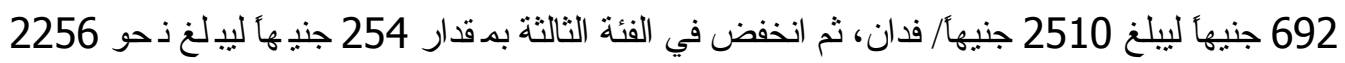

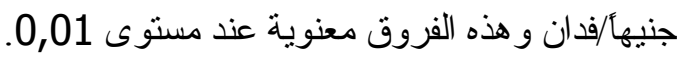

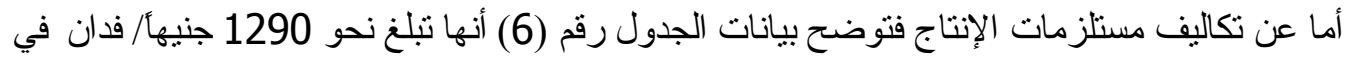

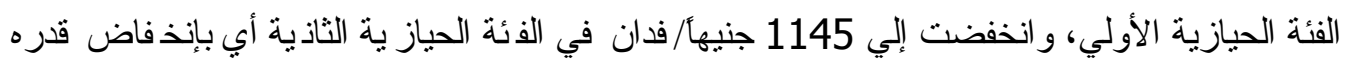

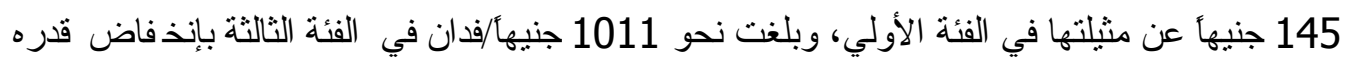

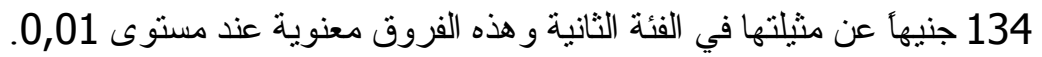

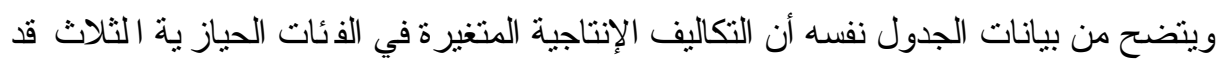

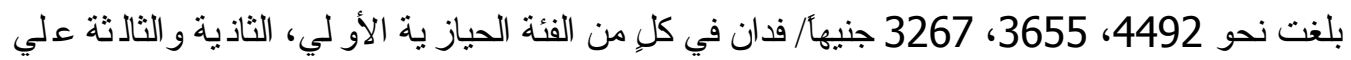

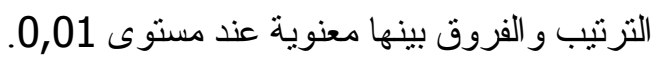
مما سبق يتبين أن بنود التكاليف الإنتاجية سالفة الذكر تتخفض قيمته ها عند الانتقال من فئة حيازية صغيرة إلي فئة حيازية أكبر، ويرجع ذلك إلي مبدأ وفور ات السعة حيث تتخفض التكاليف بز يادة حجم الإنتاج. 
الكميات المستخدمة من عناصر الإنتاج الفيزيقية واللازمة لإنتاج الفدان من مدصول الق مح (صنف

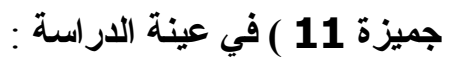

يتتاول هذا الجزء الكميات الفيزيقية من عناصر الإذتاج اللاز مة لإذناج الفدان من مدصول القمح (صنف جميزة 11)، حيث تتقم هذه العناصر إلي قسمين أولهما العمل الزر اعي بأثكاله المختلفة من عمل بشري و آلي وحيو اني وثانيه ما دـ ستلزمات الإنتاج (التّقاوي، الأسمدة الفو سفاتية و الأزوتية

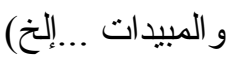
أولًا : العمل الزراعي اللازم لإتتاج الفلان من محصول القــح : ويشمل كلا من العمل البشري و العمل

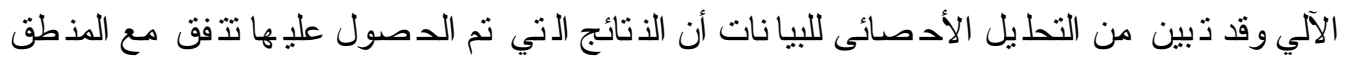
الاقتصادي و الاخصائي ويتضح ذللك فيما يلي:

جدول رقم (6) متوسط قيمة بنود التكاليف الإنتاجية للفدان من محصول القمح جميزة 11 وفقاً للفئات الحيازية وذلك بالعينة المختارة من محافظة الغربية في الموسم الزراعي 2017/2016

\begin{tabular}{|c|c|c|c|c|c|c|c|c|}
\hline المعنوية & المحسوبة & في فيمة البندين & فيمي الفئة & في الفيمة البنين & في في الفئدة البند & في الّي الفئة & & \\
\hline$* *$ & 138,13 & 83 & 753 & 438 & 836 & 1274 & \multirow{2}{*}{\multicolumn{2}{|c|}{ تكاليف العمل الحيو البشري }} \\
\hline ** & 132 & 31 & - & 34 & 31 & 65 & & \\
\hline$* *$ & 257,14 & 117 & 218 & 66 & 335 & 401 & عمل آلي جرار & \multirow{7}{*}{ 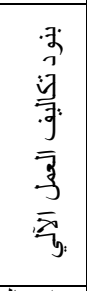 } \\
\hline- & - & 110 & 110 & - & - & - & تسوية بالليزر & \\
\hline- & - & 100 & 100 & - & - & - & زر اعة آلية & \\
\hline$* *$ & 79,86 & 131 & 232 & 30 & 363 & 393 & عمل الي ماكينة & \\
\hline$* *$ & 14,35 & 4 & 34 & 10 & 38 & 48 & مقاومة كيماوية آلية & \\
\hline$* *$ & 86,63 & 77 & 402 & 51 & 479 & 530 & حصناد & \\
\hline$* *$ & 56,85 & 21 & 407 & 63 & 428 & 491 & در اس & \\
\hline- & 95,44 & 140 & 1503 & 220 & 1643 & 1863 & \multirow{2}{*}{\multicolumn{2}{|c|}{ 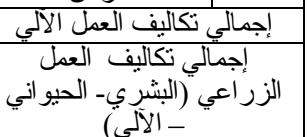 }} \\
\hline - & 224,29 & 254 & 2256 & 692 & 2510 & 3202 & & \\
\hline$* *$ & 3116,14 & 12 & 357 & 19 & 370 & 389 & التقاوي & \multirow{5}{*}{ 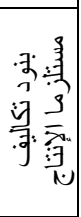 } \\
\hline$* *$ & 157,58 & 26 & 188 & 40 & 214 & 254 & السماد الفوسفاتي & \\
\hline$* *$ & 183,03 & 74 & 331 & 72 & 405 & 477 & السماد الأزوتي & \\
\hline$*$ & 3,946 & 21 & 135 & 14 & 156 & 170 & المبيدات & \\
\hline ** & 73,97 & 134 & 1011 & 145 & 1145 & 1290 & مستلزمأت الإلنتاج & \\
\hline$* *$ & 316,7 & 388 & 3267 & 837 & 3655 & 4492 & \multicolumn{2}{|c|}{ التكاليف المتغيرة } \\
\hline- & 0,41 & صفر & 4000 & 041 & 4000 & 4041 & \multicolumn{2}{|c|}{ التكالّف الثابتة } \\
\hline$* *$ & 212,85 & 883 & 7267 & 878 & 7655 & 8533 & \multicolumn{2}{|c|}{ التكاليف الكلية } \\
\hline
\end{tabular}

حيث : ** معنوية عند 0,01 ، * معنوية عند 0,05. المصدر : جمعت وحسبت من استمار ات الاستبيان لعينة الاراسة الميدانية.

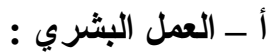

يتبين من الجدول رقم (7) أن كمية عنصر العمل البشري اللازمة لإنتاج الفدان من مدصول

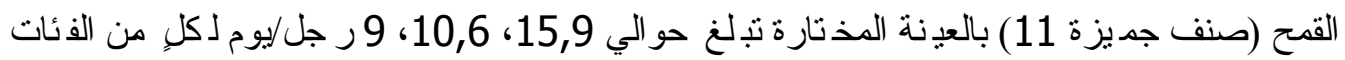
الحيازية الأولي، و الثانية و الثالثة علي الترتيب وتبين أنه توجد فروق معنوية في استخدام الع مل الب شري بين الفئات الحيازية الثناث عند مستوي معنوية 0,01 


\section{بـ العمل الآلي : ويشمل كلاً مما يأتي :}

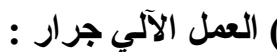

يتضح من بيانات الجدول رقم (7) أن كمية العمل الآلي جر ار تتفاوت من فئة حياز ية لآخري

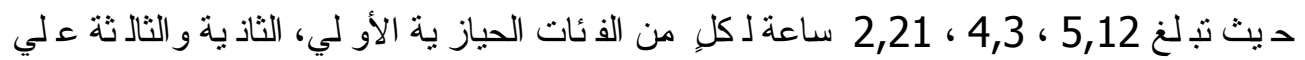
التزتيب، وتبين كذلك وجود فروق ،

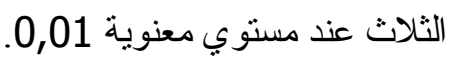

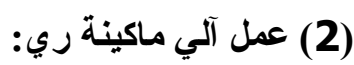

وتوضح بيانات الجدول رقم (7) أن عدد ساعات العمل الآلي لماكينة الري الكاعل الكاز مة لإنتاج

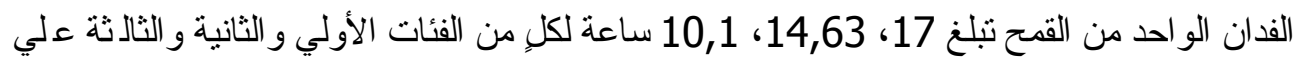

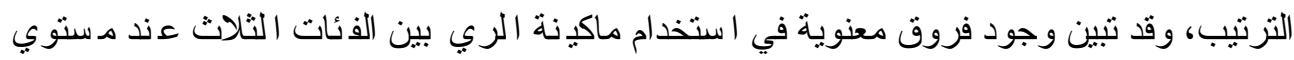

$$
\text { معنوية 0,01. }
$$$$
\text { عمل آلي (موتور رش) : }
$$

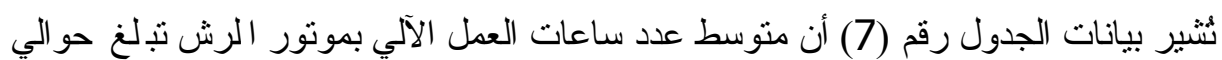

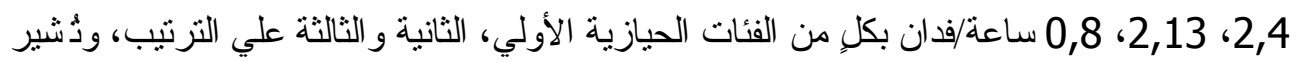

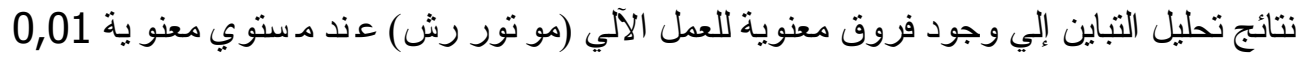

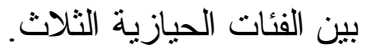

(4) (4) الحصاد الآلي : (4)

توضح بيانات الجدول رقم (7) أن متوسط عدد ساعات العمل الآلي اللاز مة لدصاد الداد الـدان

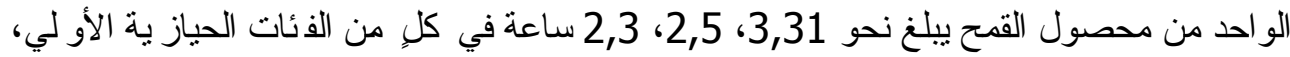

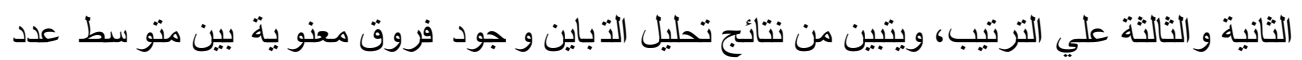

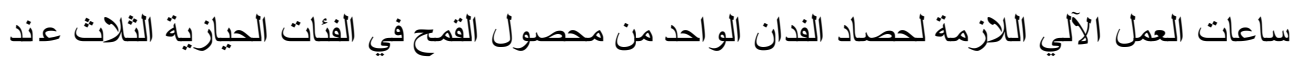

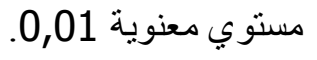

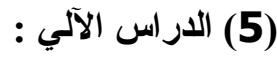

يتضح من بيانات الجدول رقم (7) أن منوسط عدد ساعات العمل الآلي اللازمة لدر اس الفدان

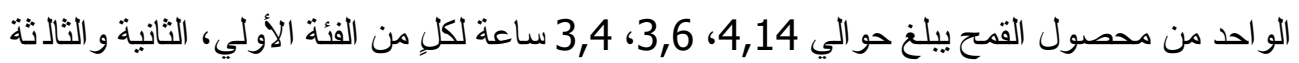

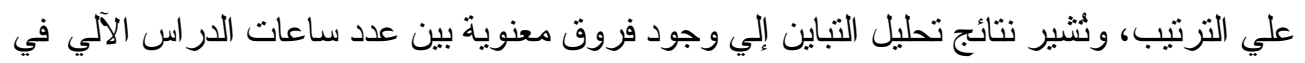
الفئات الحيازية الثلاث عند مستوي معنوية 0,01. ثانياً : مستلزمات الإتتاج اللازمة لإتتاج القدان من محصول القمح :

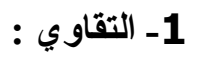

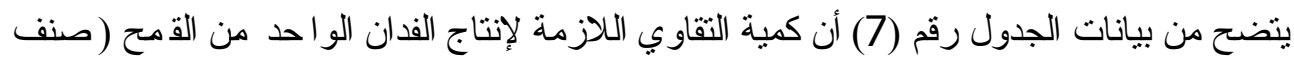

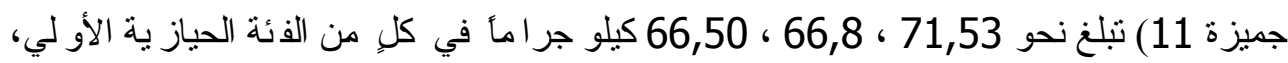

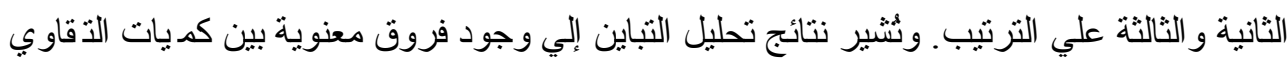

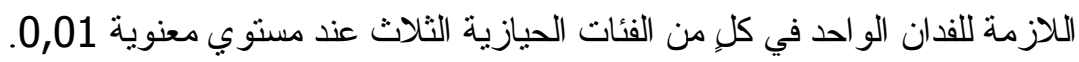


جدول رقم (7) كميات عناصر الإتتاج اللازمة لإنتاج الفدان الواحد من محصول القمح (صنف جميزة

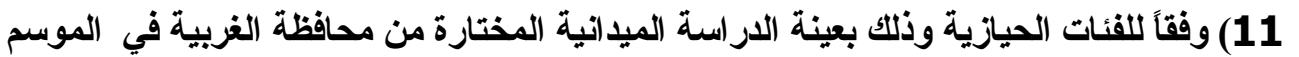

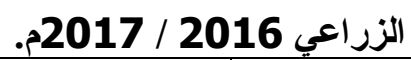

\begin{tabular}{|c|c|c|c|c|c|c|c|}
\hline \multirow{2}{*}{ قو F المحسوبة } & \multicolumn{3}{|c|}{ كمية العنصر الإنتاجي اللازمة لإنتاج الفدان } & \multicolumn{4}{|c|}{ العنصر الإنتاجي } \\
\hline & في الفئة & في الفئة & في الفئة & وحدة & العن مز & 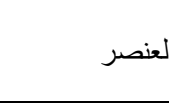 & \\
\hline${ }^{* *}(127,09)$ & 9 & 10,6 & 15,9 & رجل ليوم & $\mathrm{X}_{1}$ & \multicolumn{2}{|c|}{ العمل البشري } \\
\hline${ }^{* *}(45,62)$ & 2,21 & 4,3 & 5,12 & ساعة & $X_{2}$ & 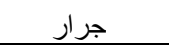 & \multirow{5}{*}{ العمل الآلي } \\
\hline${ }^{* *}(38,37)$ & 10,10 & 14,63 & 17 & ساعة & $X_{5}$ & ماكينة ري & \\
\hline${ }^{* *}(28,55)$ & 0,8 & 2,13 & 2,4 & ساعة & $X_{6}$ & مونور رش & \\
\hline${ }^{* *}(17,84)$ & 2,3 & 2,5 & 3,3 & 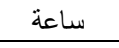 & $X_{7}$ & حصاد آلي & \\
\hline${ }^{* *}(13,20)$ & 3,4 & 3,6 & 4,14 & 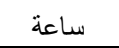 & $\mathrm{X}_{8}$ & 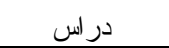 & \\
\hline${ }^{* * *}(89,75)$ & 66,5 & 66,8 & 71,53 & كيلو جر ام & $X_{9}$ & 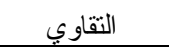 & \\
\hline${ }^{* *}(167,58)$ & 21,7 & 28,3 & 37,6 & فوسفرة & $\mathrm{X}_{10}$ & السماد الفوسفاتي & مستلزمات \\
\hline${ }^{* *}(229,74)$ & 44,18 & 52,42 & 70,43 & وحدة & $X_{11}$ & السماد الآزوتي & الإنتاج \\
\hline${ }^{* *}(34,58)$ & 129,6 & 155,7 & 170,25 & جنيه & $A_{12}$ & المبيدات & \\
\hline
\end{tabular}

حيث : ** تُشبر إلي المعنوية عند $0,01$.

- إجمالي مساحة الفئة الأولي 52 فداناً ، إجمالي مساحة الفئة الثانية 64 فداناً ، إجمالي مساحة الفئة الثالثة 60 فداناً .

المصدر : جمعت وحسبت من استمارات استبيان عينة الاراسة الميدانية. 2- السماد الفوسفاتي:

توضح بيانات الجدول رقم (7) أن كمية السماد الفوسفاتي اللازمة لإنتاج الفدان الو احد من مدصول

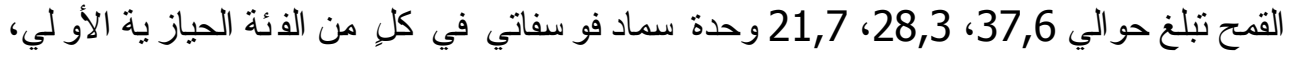

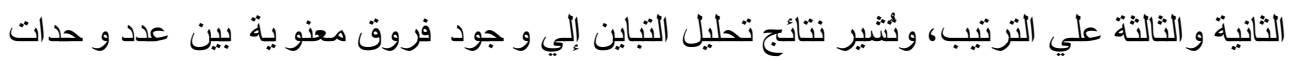

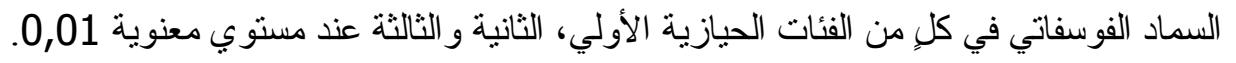

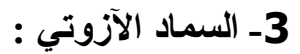
توضح البيانات الواردة بالجدول رقم (7) أن كمية السماد الآزوتي اللازمة لإنتاج الافدان الو احد من

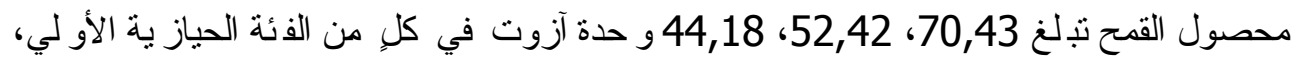

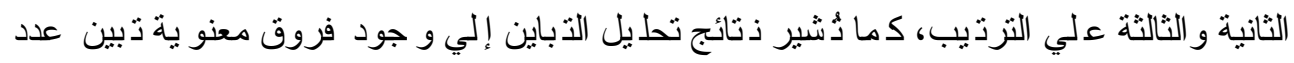
الوحدات الآزوتية اللازمة لإتتاج الفدان الواحد في كلٍ من الفئات الحياز ية الأو لي، الثاذية و الثنالثة

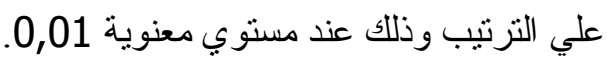
4- المبيدات : تختلف وحدة قياس المبيدات فقد تكون باللتر أو بالكيلو جر ام و قد تكون سائلة أو جافة في صورة

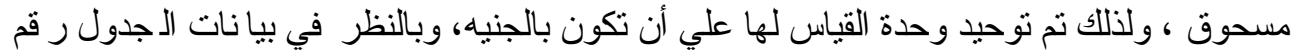

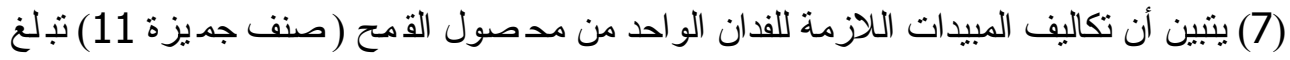


نحو 170,25، 155,7، 129,6 جنيهأ لكلٍِ من الفئة الأولي، الثانية و الثالثة علي التزنيب ويتضح

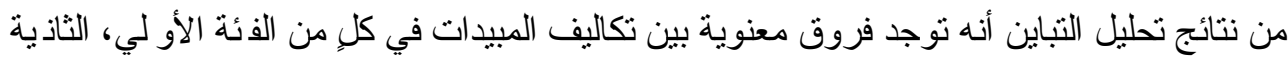

$$
\text { و الثالثة علي الترتيب وذللك عند مستوي معنوية 0,01. }
$$

المقاييس المطلة و النسبية للكفاءة الاقتصادية لإنتاج الفدان الواحد من محصول القمح (صنف جميزة

11) بعينة الدراسة الميدانية:

أولاً: أهم المقاييس المطلة للكفة الكاءة الاقتصادية:

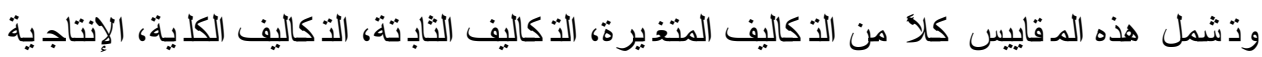
الفدانية، قيمة الناتج الرئيسي بالجنيه، إجمالي العائد بالجنيه، الفائض الحدي (العائد فوق التكاليف المتغيرة) و أخير أ صافي العائد الفداني بالجنيه.

1- 1 التكاليف الإنتاجية المتغيرة:

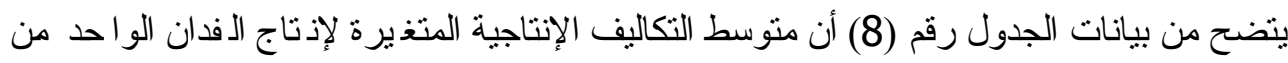

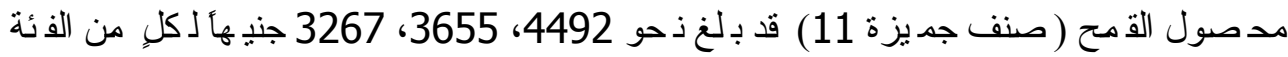

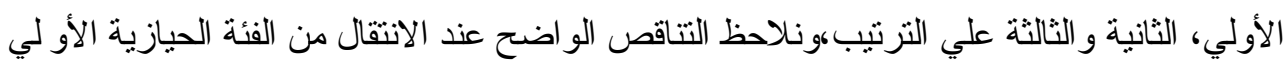

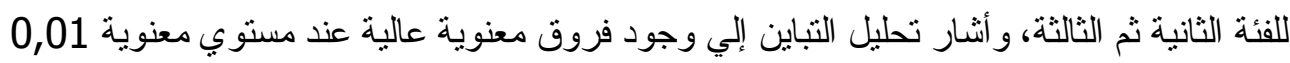

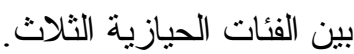
2- 2 - 2 - 2 التكاليف الإنتاجية الثابتة:

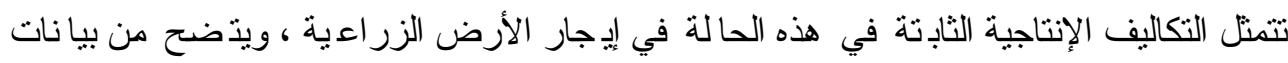

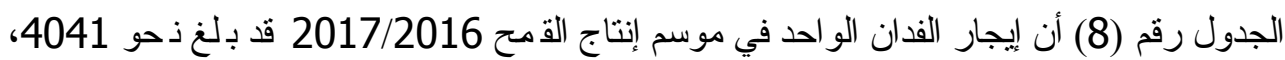

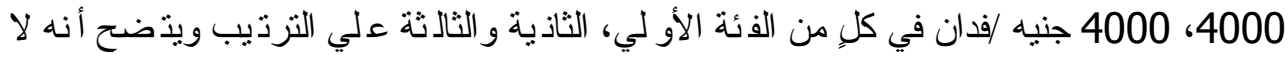
توجد فروق معنوية بين الإيجار في الفئات الثثلاث عند كل مستويات المعنوية المألوفة.

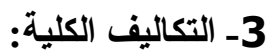

يتضح من بيانات الجدول رقم (8) أن الت كاليف الإنتاجية الكاية لافدان الو احد من مدصول الق مح

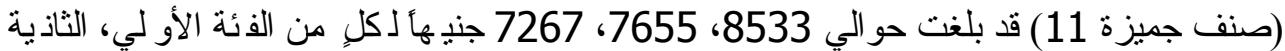

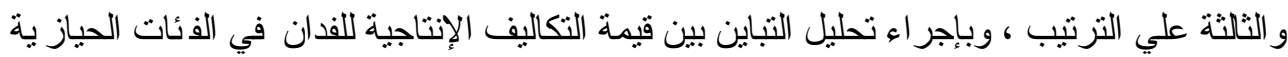

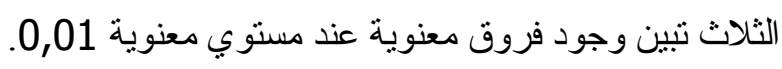
4- الإنتاجية الفدانية (أردب /فدان) :

تعبر الإنتاجية الفدانية (أردب/فدان) عن متوسط إذتاج الافدان من القمح في المو سم، وتعتبر الإنتاجية

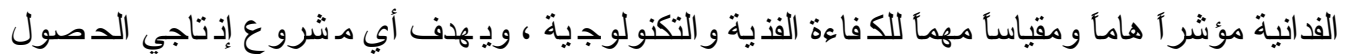

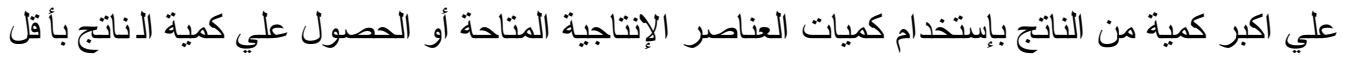

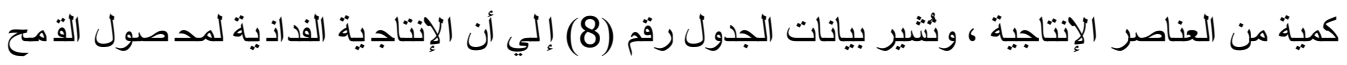
(صنف جميزة 11) تبلغ نحو 18,16، 19,34، 21,8 أردب /فدان في كلٍ من الفئات الأو لي، الثانية

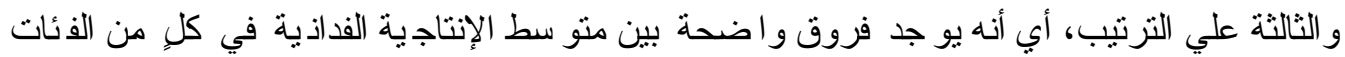
الحيازية الثلاث، الأمر الذي أدي إلي وجود فروق معنوية الثية عالية عند مستوي معنو ية 0,01 بين الفئئات

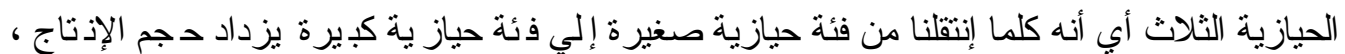
ويرجع ذلك إلي مبدأ وفور ات السعة. 
5- 5 - 5 إجمالي العائد بالجنيه :

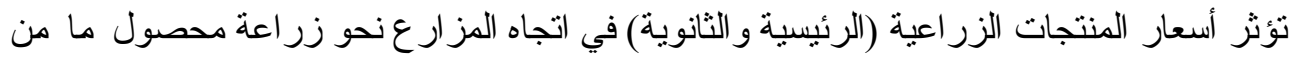

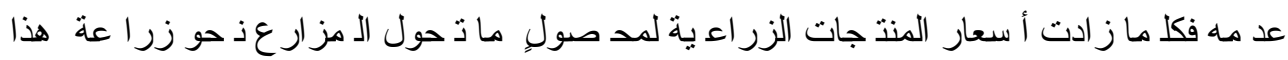

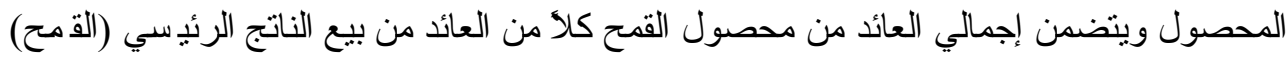

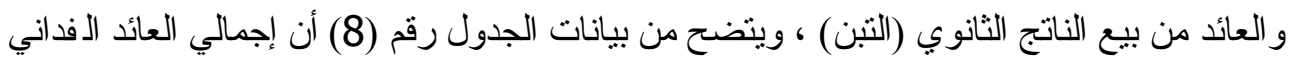

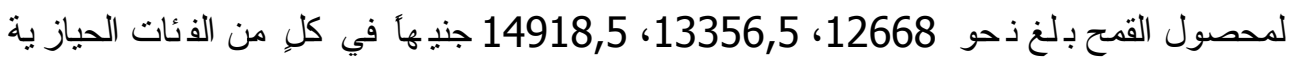

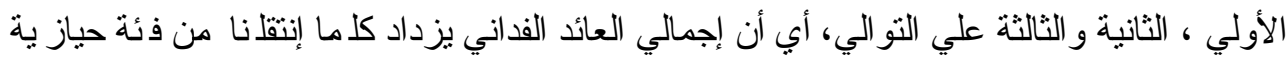

إلي فئة حيازية أكبر منها. 6- الفائض الحدي (العائد فوق التكاليف المتغيرة) أو الهامش الإجمالي للفدان :

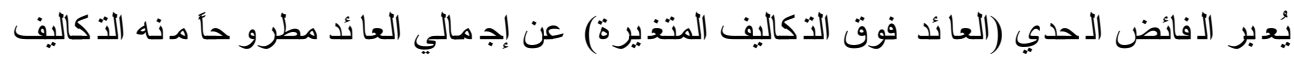

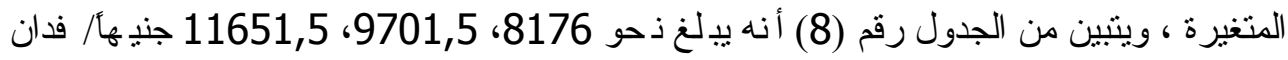

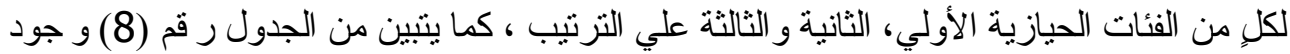

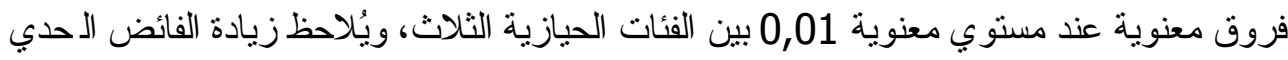

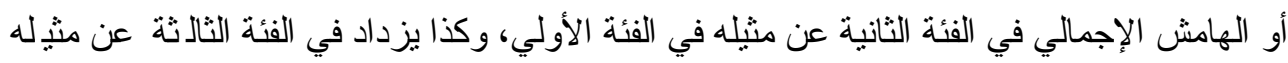

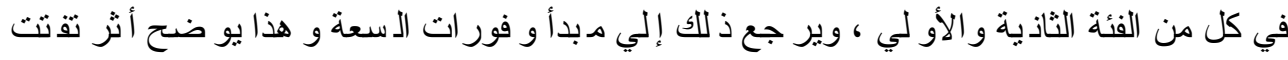
الأر اضي الزر اعية علي التكاليف و العائد.

جدول رقم (8) المقاييس الاقتصادية لإتتاج الفدان الواحد من محصول القمح (صنف جميزة 11)

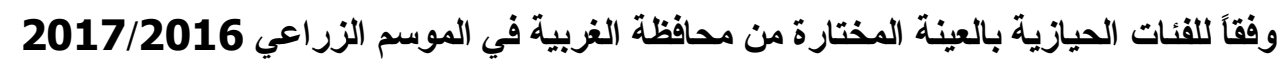
(القيمة بالجنيه)

\begin{tabular}{|c|c|c|c|c|c|}
\hline F قيمة المحسوبة & قالفئة الحيازية المقياس في & قالفئة الحيازية فية & قيمة المقياس في الفئة & & \\
\hline${ }^{* *}(316,7)$ & 3267 & 3655 & 4492 & التكاليف المتغيرة & \multirow{9}{*}{$\begin{array}{l}\overline{\bar{g}} \\
\bar{z} \\
\overline{3} \\
\bar{y} \\
\overline{7}\end{array}$} \\
\hline$(0,413)$ & 4000 & 4000 & 4041 & التكاليف الثابتة (الإيجار ) & \\
\hline$* *(212,85)$ & 7267 & 7655 & 8533 & التكاليف الكلية & \\
\hline${ }^{* *}(399,44)$ & 21,8 & 19,34 & 18,16 & الإنتاجية الفدانية أردب /فدان & \\
\hline${ }^{* * *}(847,9)$ & 12317 & 10927 & 10260 & قيمة الناتج الرئيسي بالجنيه & \\
\hline$* *(98,76)$ & 12,1 & 11,3 & 11,2 & كمية الناتج الثانوي (حمل /فدان) & \\
\hline${ }^{* *}(79,76)$ & 2601,5 & 2429,5 & 2408 & قيمة الناتج الثانوي بالجنيه & \\
\hline$* *(369,12)$ & 14918.5 & 13356,5 & 12668 & إجمالي العائد بالجنيه & \\
\hline${ }^{* *}(171,3)$ & 11651,5 & 9701,5 & 8176 & الفائض الحدي (العائد فوق التكاليف المتغيرة) & \\
\hline ** $(214,26)$ & 7651,5 & 5701,5 & 4135 & صافي العائد بالجنيه (إجمالي العائد & \\
\hline${ }^{* *}(56,68)$ & 2,1 & 1,74 & 1,5 & إجمالي العائد / إجمالي التكاليف & \multirow{4}{*}{ 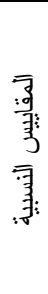 } \\
\hline${ }^{* *}(23,43)$ & 1,1 & 0,74 & 0,5 & ربحية الجنيه المستثمر (صافي التكائي & \\
\hline${ }^{* *}(120,74$ & $\% 210$ & $\% 174$ & $\% 150$ & 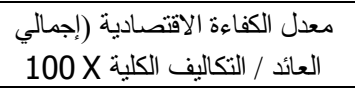 & \\
\hline${ }^{* *}(37,53)$ & $\% 51,29$ & $\% 42,69$ & $\% 32,64$ & نسبة هامش الربح للمنتج (صافي الجمالي العمائد & \\
\hline
\end{tabular}

حيث: ** ثُشير إلي المعنوية عند مستوي 0,01.

ـ متوسط سعر الأردب من القمح 565جنيهاً ، متوسط سعر الحمل من التبن 215جنيهاً. المصدر : جُمعت وحسبت من استمارات الاستبيان لعينة الاراسة الميدانية. 
7 - صافي العائد القداني بالجنيه:

و هو عبارة عن إجمالي العائد مطرو حأ منه التكاليف الكاية ، و هو من أ هم الدقاييس الاقتصادية

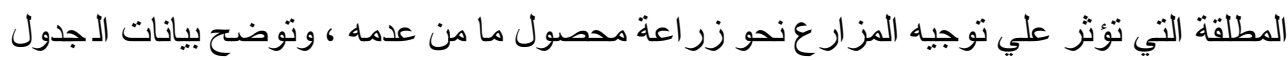

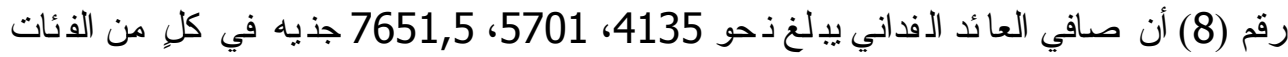

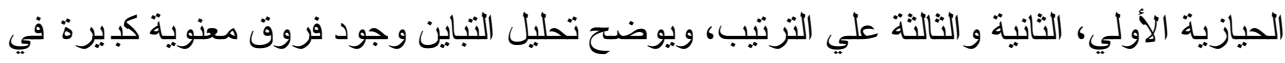

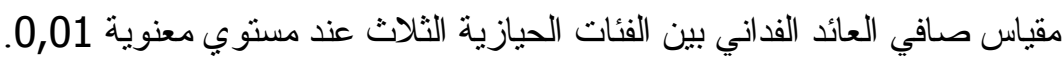

ثانياً : المقاييس النسبية :

1- إجمالي العائد / إجمالي التكاليف :

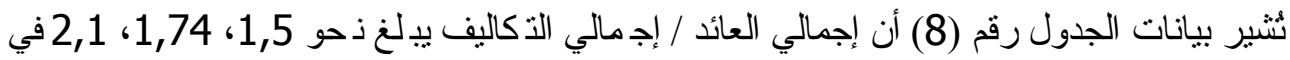

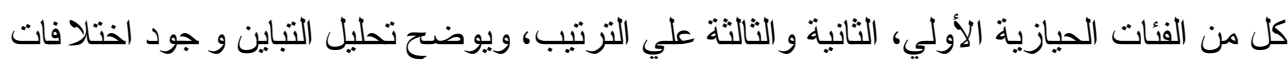
جو هرية وفروق معنوية كبيرة عند مستوي معنوية 0,01 بين الفئات الثناث. 2- 2 ربحية الجنيه المستثمر :

و هذا المقياس عبارة عن صافي العائد مقسومأ علي التكاليف الكلية، ويتضح من بيانات الاجدول ر قم

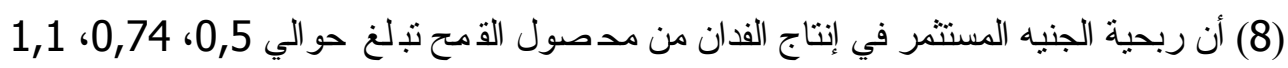

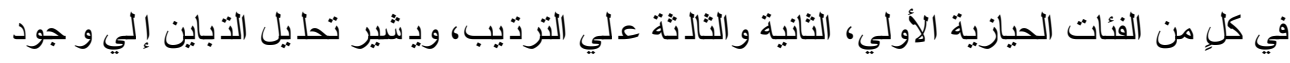

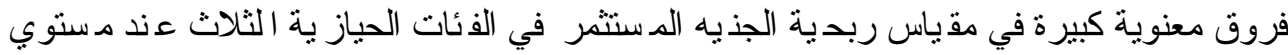

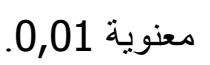

3- معدل الكفاءة الاقتصادية : معنة

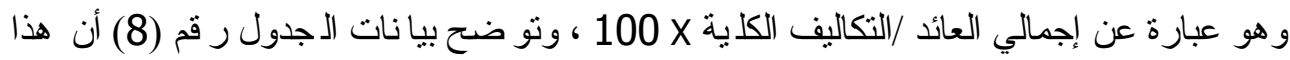

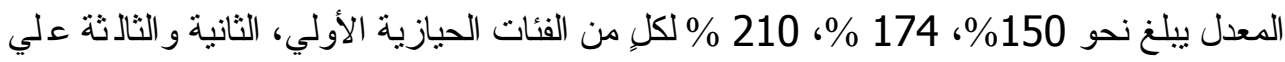

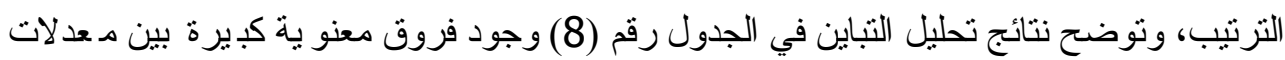

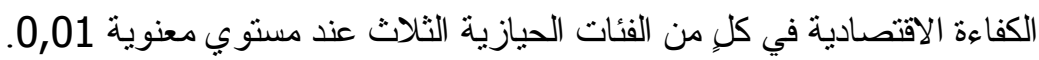

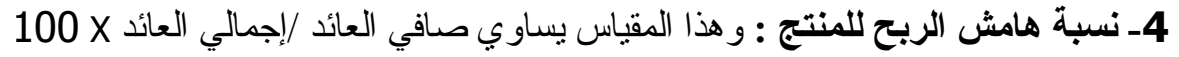

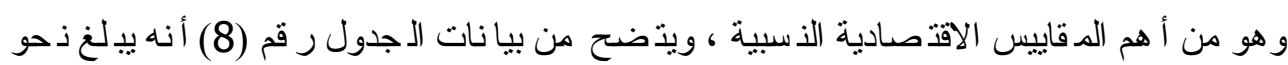

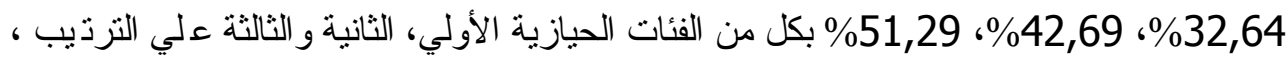

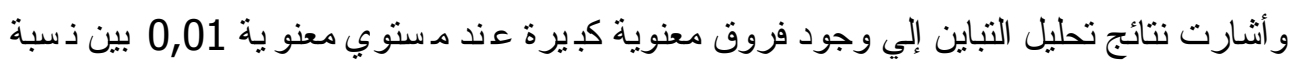

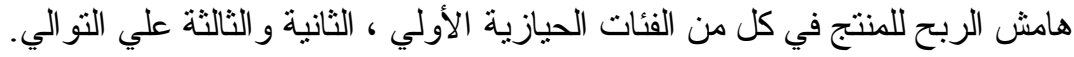
التقدير القياسي لاوال إنتاج محصول القمح (صنف جميزة 11) بعينة الدراسة :

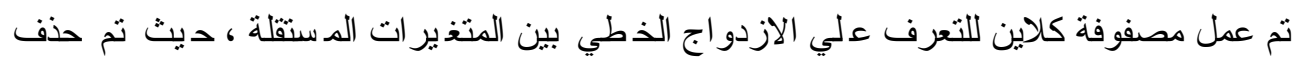

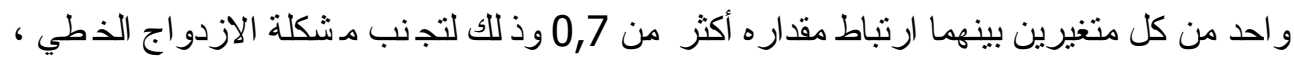

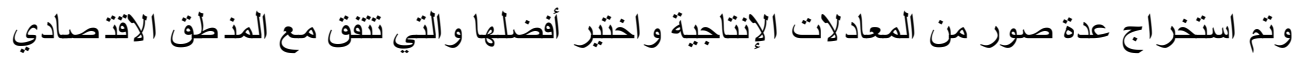

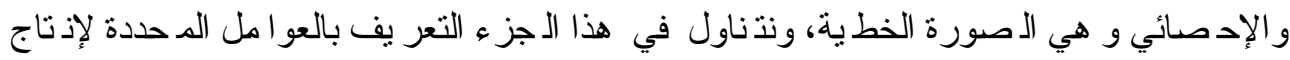

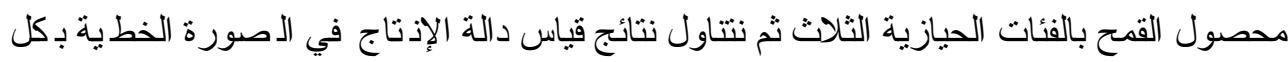
فئة من الفئات المذكورة. 
جدول رقم (9) دالات إتتاج محصول القمح (صنف جميزة 11) في الصورة الخطية وفقاً للفئات الحيازية

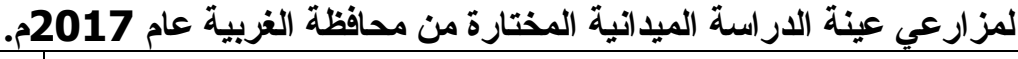

\begin{tabular}{|c|c|c|c|c|c|}
\hline المعنوية & $\mathrm{F}$ & $\mathrm{R}^{2}$ & المعادلة & الفنّة البيان & لمعادلة \\
\hline$* *$ & 33.941 & 0.66 & $\begin{array}{l}\hat{\gamma}_{1=0.522+0.100 \mathrm{x}_{9}+1.873 \mathrm{x}_{8}+0.180 \mathrm{x}_{5}} \\
(0.485)(4.995)^{* *}(3.614)^{* *}(2.635)^{* *}\end{array}$ & الأولي & 1 \\
\hline$* *$ & 99.933 & 0.91 & $\begin{array}{c}\hat{\gamma}_{2=6.500+0.310 x_{10}+0.532 x_{1}+0.083 x_{11}+1.799 x_{7}} \\
(3.343)^{* *}(4.158)^{*}(2.786)^{* *}(3.117)^{* *}(2.223)^{*}\end{array}$ & الثانية & 2 \\
\hline$* *$ & 70.291 & 0.88 & $\begin{array}{c}\hat{\gamma}_{3}=8.514+0.228 \mathrm{x}_{9}+0.064 \mathrm{x}_{11} \\
(1.264)(6.148)^{* *}(2.931)^{* *}\end{array}$ & الثالثة & 3 \\
\hline
\end{tabular}

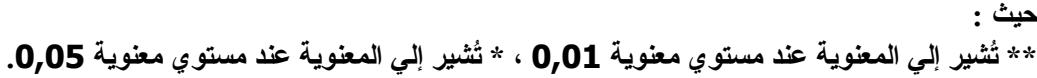
المصدر : نتائج تحليل بيانات عينة الار اسة الميدانية.

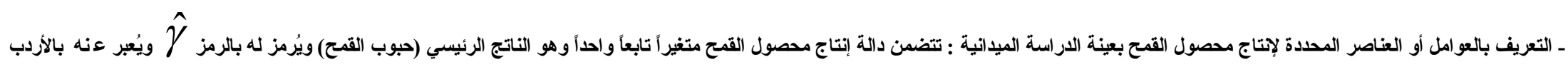

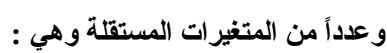
: X1 X X

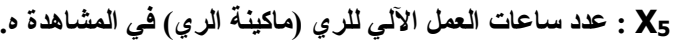

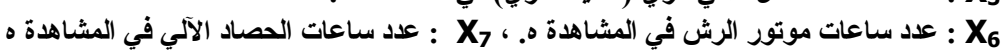
X8

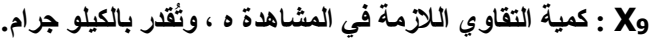

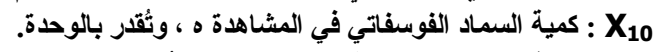
X11 : كمية السماد الآزوتي في المشاهدة ه ه ، وثُقر بالوحدة. 
(1) نتائج قياس دالة إنتاج محصول القمح (صنف جميزة 11) في الصورة الخطية للفئة الحياز ية الأولى:

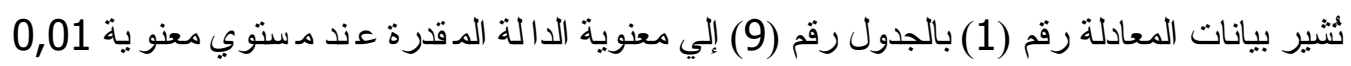

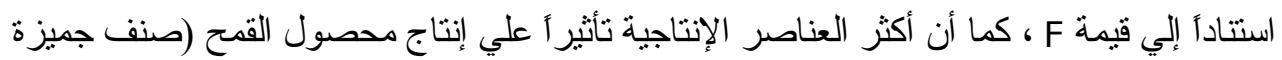

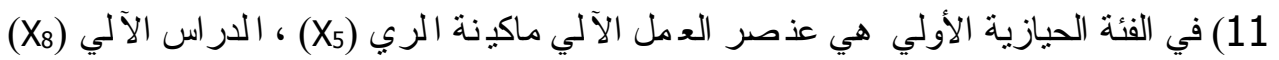

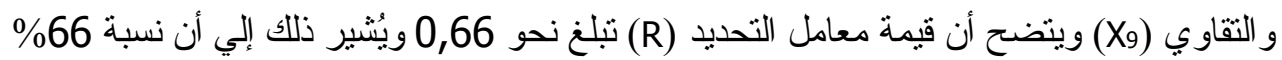
من التغير ات في الناتج الكلي من القمح (صنف جميزة)

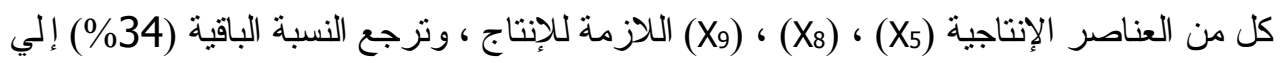
عو امل أخري غير مدروسة.

(2) نتائج قياس دالة إنتاج محصول القمح (صنف جميزة 11) في ال صورة الخطية للفئة الحياز ية الثانية:

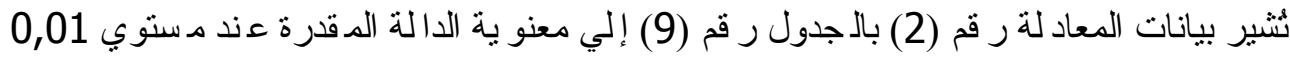

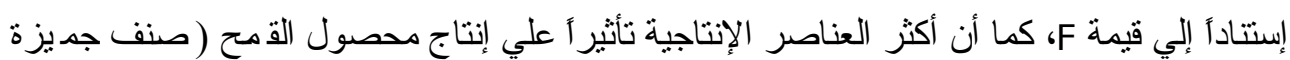

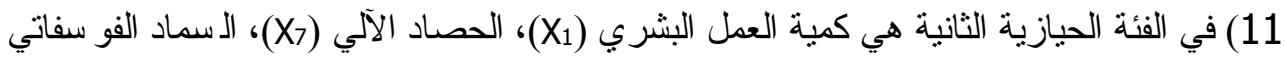

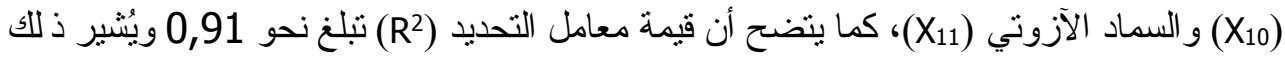

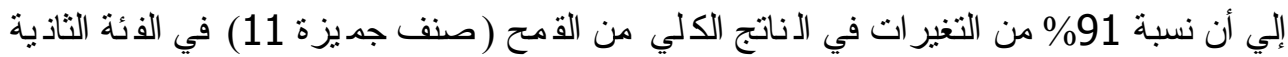

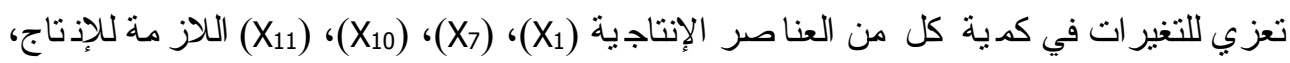
وترجع النسبة الباقية (9\%) إلي عو امل أخري غير فير مدروسة. (3) نتائج قياس دالة إنتاج محصول القمح (صنف جميزة 11) في الـ صورة الخطية للفئة الحياز ية الثالثة: كُشير بيانات المعادلة رقم (3) بالجدول ر قم (9) إلي معنو ية الدالة الد قدرة عند مـ ستوي معنو ية

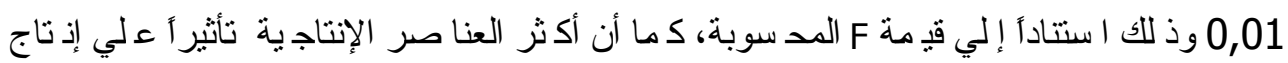
محصول القمح (صنف جميزة 11) في الفئة الحياز ية الثالثة هـ ما عذصري التقاوي (X9) و الـماد

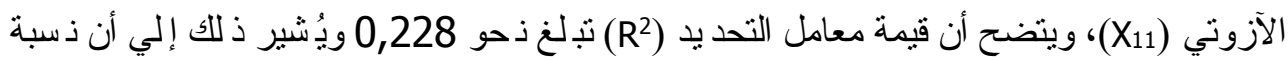

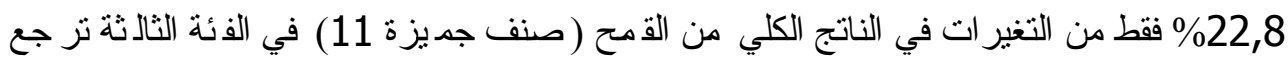

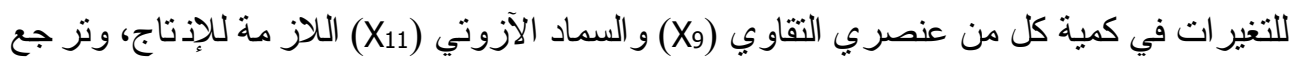
النسبة الباقية (76,2\%) إلي عو امل أخري غير غير مدروسة.

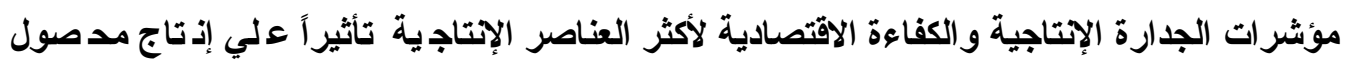
القمح (صنف جميزة 11): مؤنزات للتعرف علي الكفاءة الاقتصادية لأكثر العناصر الإنتاجية تأثثر آ علي إنتاج القمح (صنف جميزة 11) يتم

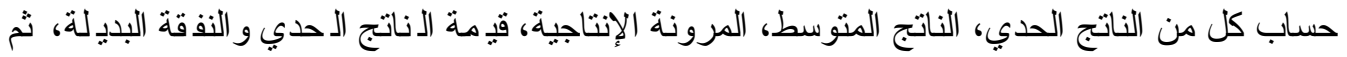

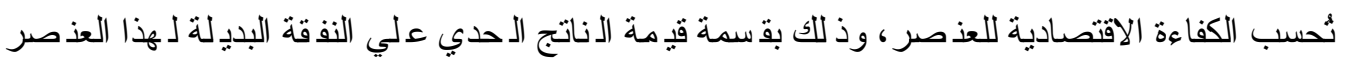
و المنتكلة في سعر الوحدة من العنصر الإنتاجي. 1- مؤشرات الجدارة الإتتاجية للعناصر الإنتاجية الداخلة في نموذج الإنية الدالة الإنتاجية بـكلٍ من الفئات

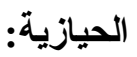
و هذه المؤشرات عبارة عن الناتج الحدي، الناتج المنوسطو المرو نة الإنتاجية، و قد نم حساب هذه

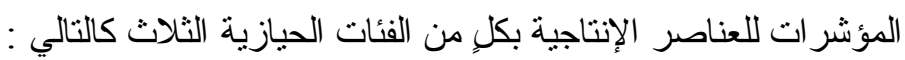


(أ) مؤشرات الجدارة الإنتاجية للعناصر الإنتاجية الداخلة في نموذج الدالة الإنتاجية بالف ئة الحياز ية

يتضح من بيانات الجدول رقم (10) أن معامل المرونة الإنتاجية لعنصر الع مل الآلي ماكينة الري

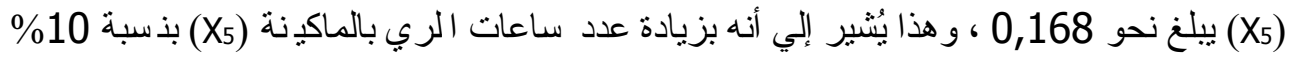

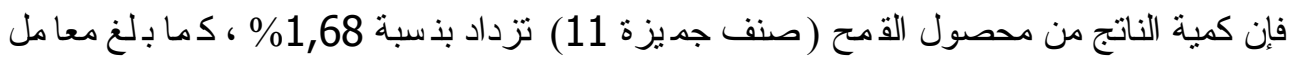

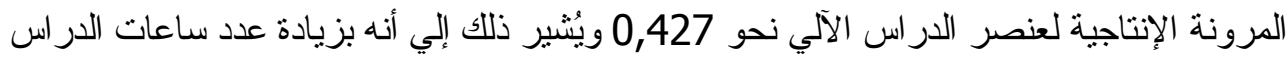

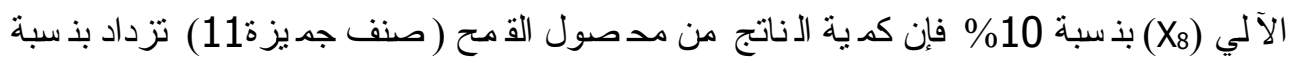

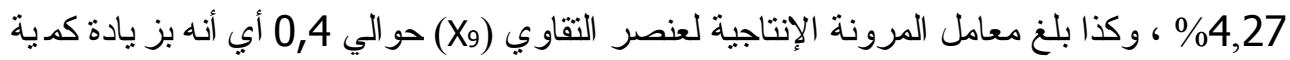

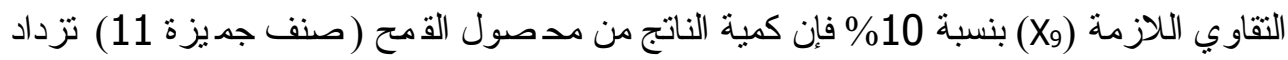

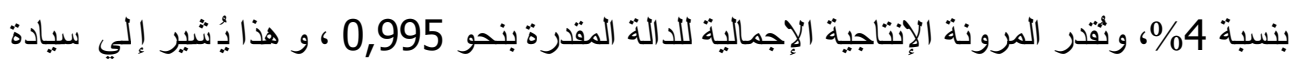

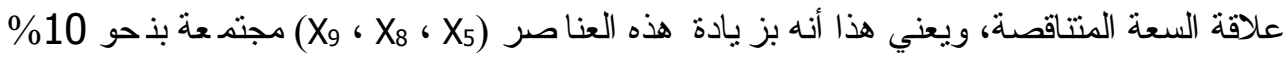

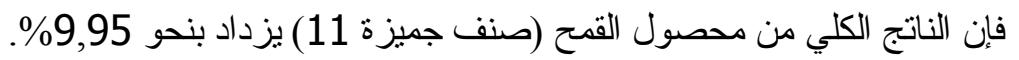
(ب) مؤشرات الجدارة الإنتاجية للعناصر الإنتاجية الداخلة في نموذج الداج الدانة الإنتاجية بالفئة الحياز يـة

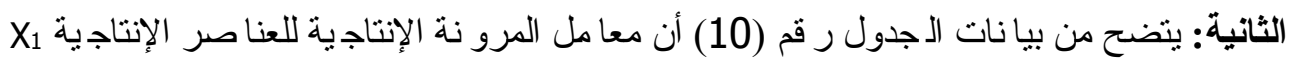

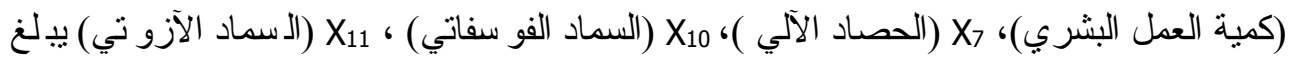

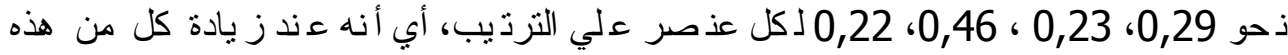

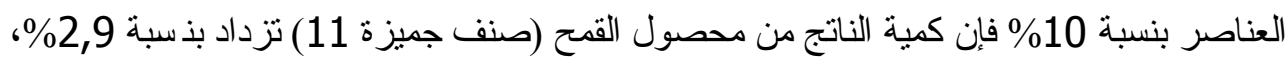

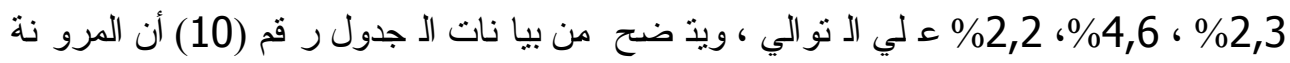

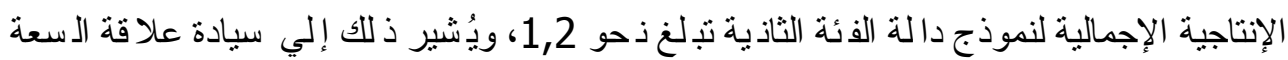

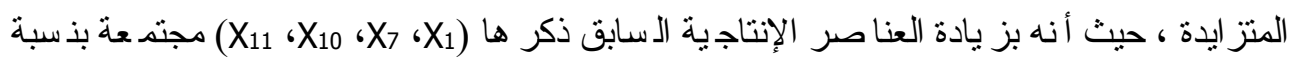

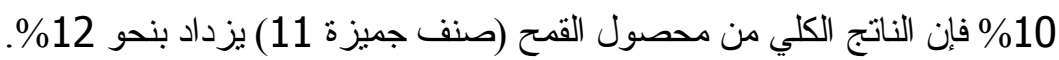
ج- مؤشرات الجدارة الإنتاجية للعناصر الإنتاجية الداخلة في نموذج الدالة الإلة الإنتاجية بالف ئة الحياز يـة الثالثة: - (الثرات

يتضح من بيانات الجدول رقم (10) أن معامل المرونة الإنتاجية لكلٍ من العنصرين الإنتاجيين

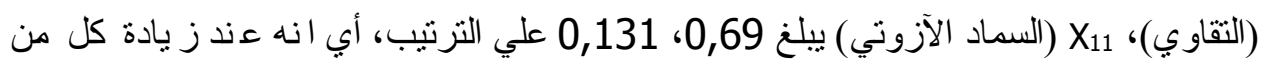

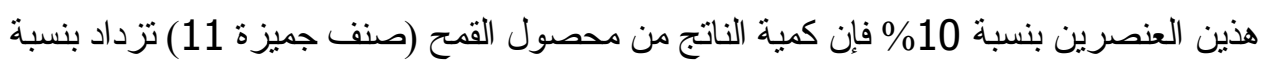

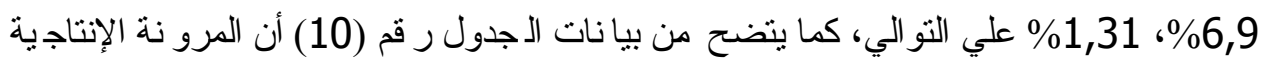

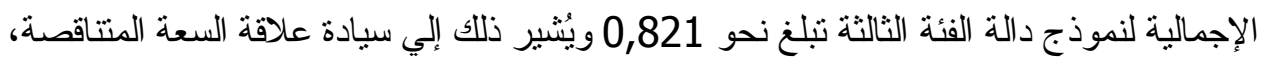

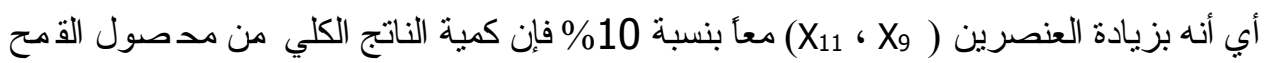

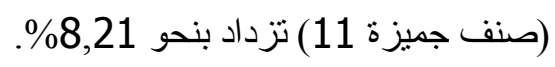

2- قياس الكفاءة الاقتصادية لأكثر العناصر الإتتاجية تأثيراً علي إنتاج محصول القمح (صنف جميزة

ثُقاس الكفاءة الاقتصادية للعنصر الإنتاجي بمعايير متعددة، وفي هذا البحث تم اختيار المعيار الناتج من

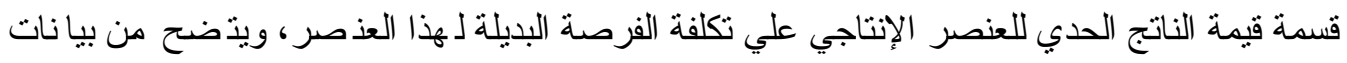

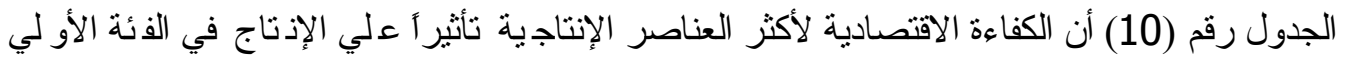

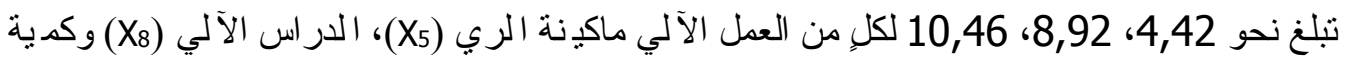

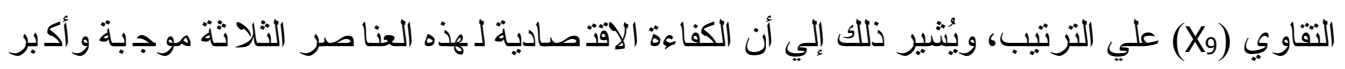


من الوا حد الصحيح، و يدل ذلك علي أن الدقدار الدستخدم يـكون أقل من القدر الذي يدقق الكفاءة

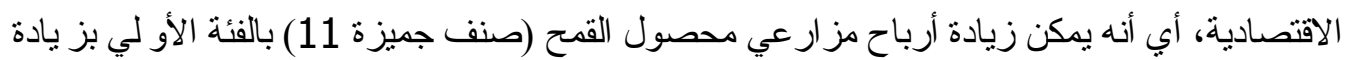

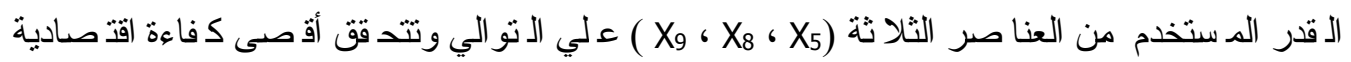

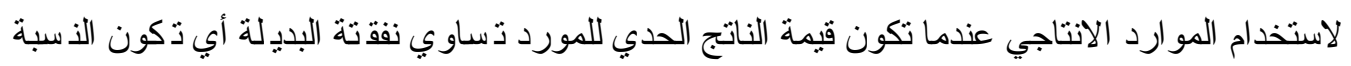

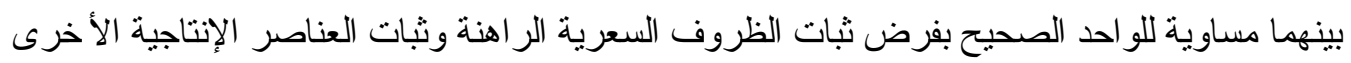
عند متوسطاتها. كما يتضح من بيانات الجدول ر قم (10) أن الكفاءة الاقتصادية لأكثر العناصر الإنتاجية تأثثر آ علي

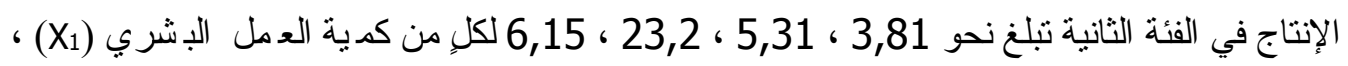

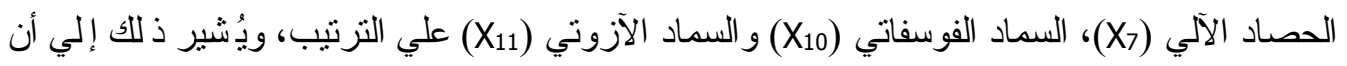

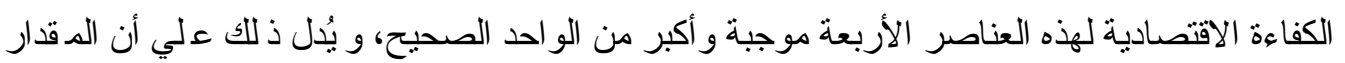

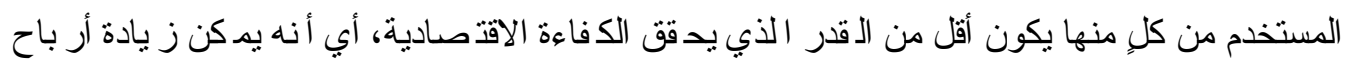

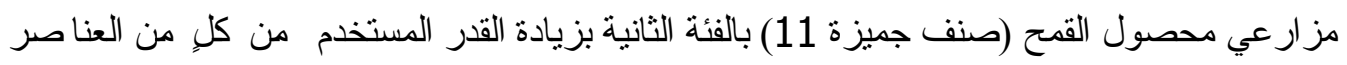

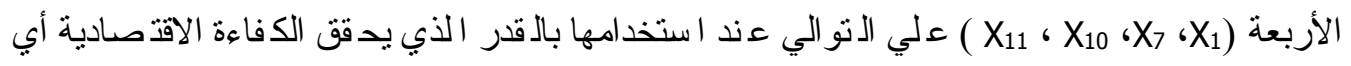

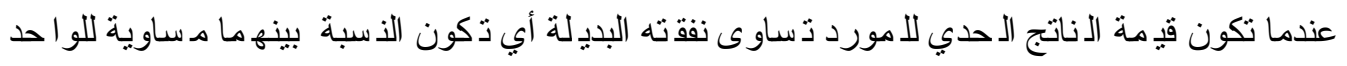

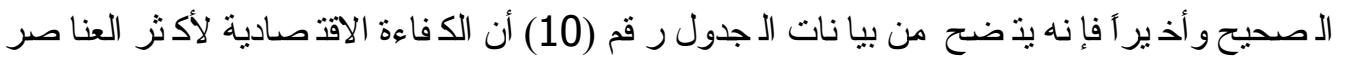

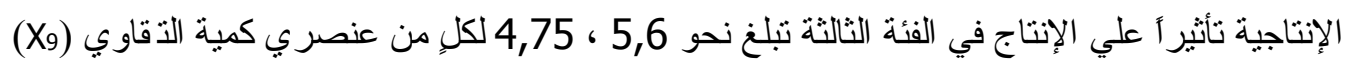

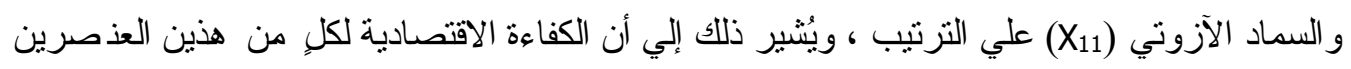

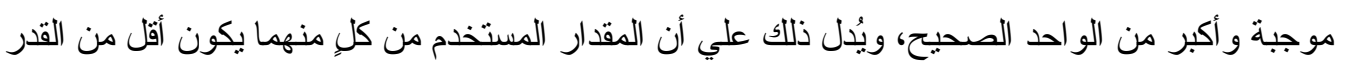

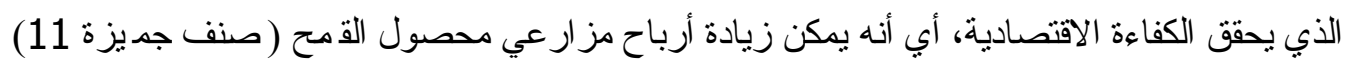

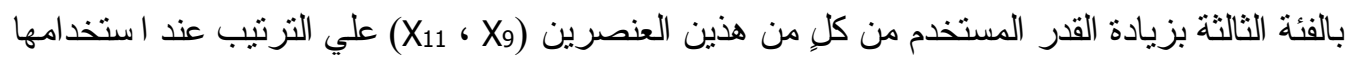

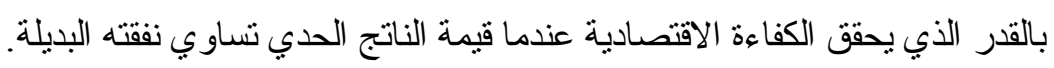


جدول رقم (10) مؤثدرات الجدارة الإتتاجية لأكثر العناصر الإتاجية تأثيراً علي إنتاج محصول القمح وفقاً للفئة الحيازية وذلك

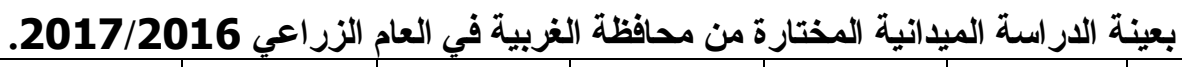

\begin{tabular}{|c|c|c|c|c|c|c|c|c|c|}
\hline الاقتصادية & للعنصر (جنيه) & الحذي للعنصة الناتجر & الإلتاجية & الناتج المتوسط & اللاتجنصر الحدي & 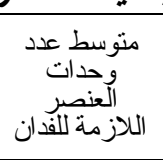 & رمز العنصر & السم العنصر & 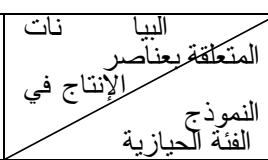 \\
\hline 4,42 & 23 & 101,7 & 0,168 & 1,07 & 0,180 & 17,02 ساعة & $X_{5}$ & ماكنة الي & \multirow{3}{*}{ الفئة الأولي } \\
\hline 8,92 & 118,62 & 1058,25 & 0,427 & 4,39 & 1,873 & 4,14 ساعة & $X_{8}$ & الدار البيه الآلّي & \\
\hline 10,46 & 5,4 & 56,5 & 0,400 & 0,25 & $\frac{1,0,100}{0,100}$ & 71,53 كجم & $X_{9}$ & الآثقاوي & \\
\hline & & & 0,995 & \multicolumn{6}{|c|}{ المرونة الإنتاجية الإجمالية لنموذج دالةُ الفئة الاولي } \\
\hline 3,81 & 78,83 & 300,58 & 0,29 & 1,82 & 0,532 & 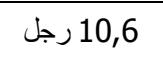 & $\mathrm{X}_{1}$ & كمينة العمل & \multirow{4}{*}{ الفئة الثانية } \\
\hline 5,31 & 191,6 & 1016,44 & 0,23 & 7,74 & 1,799 & 2,5 ساعة & $\mathrm{X}_{7}$ & الحصناد الألمي & \\
\hline 23,2 & 7,55 & 175,15 & 0,46 & 0,68 & 0,310 & 28,3 وحدة & $\mathrm{X}_{10}$ & الفوسفاتي & \\
\hline 6,15 & 7,62 & 46,895 & 0,22 & 0,37 & 0,083 & 52,42 وحدة & $\mathrm{X}_{11}$ & الآزوتيمي & \\
\hline & & & 1,20 & \multicolumn{6}{|c|}{ المرونة الإنتاجية الإجمالية لنموذج دالة الفئة التنانية } \\
\hline 5,6 & 23 & 128,82 & 0,69 & 0,33 & 0,228 & 66,5 كجم & $\mathrm{X}_{9}$ & التُقاو ي & \multirow[b]{2}{*}{ الفئة الثالثة } \\
\hline 4,75 & 7,62 & 36,16 & 0,131 & 0,49 & 0,064 & 44,18 وحدة & $\mathrm{X}_{11}$ & الآلسمتي & \\
\hline & & & 0,821 & & & & الثالثة & النموذج دالّة الفئَّة & المرونة الإنتاجية الإجمالية \\
\hline
\end{tabular}

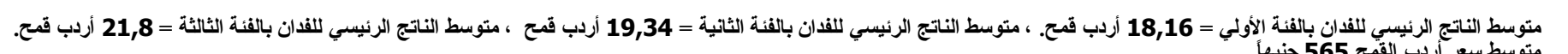

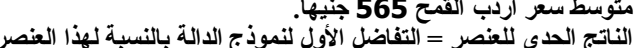

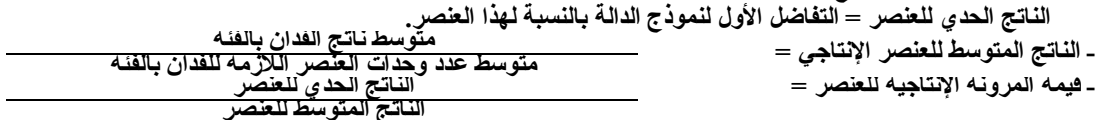

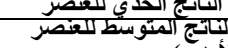

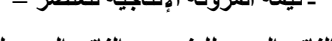

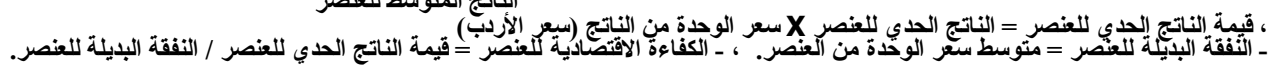




\section{أهم المشاكل و المعوقات التي تواجه مزارعي محصول القمح بمحافظة الغربية :}

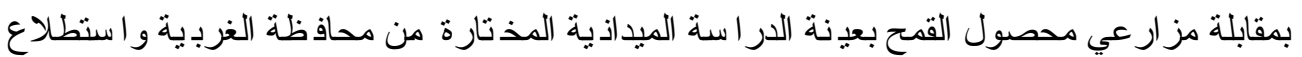

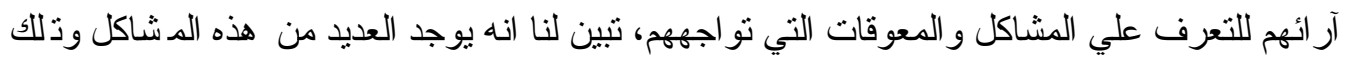

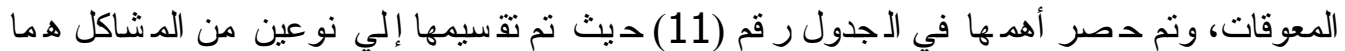
المشاكل الإنتاجية و المشاكل التسويقية.

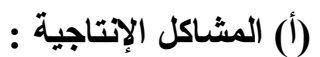
يتضح من بيانات الجدول رقم (11) أن مشكلة ارتفاع أجور العمال الزر اعيين و عدم توفرهم

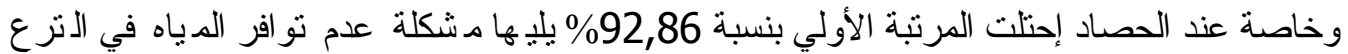
و المساقي في أوقات كثثرة أثثاء الموسم بنسبة 87,14\% ، وأما مشكلة ارتفاع أسعار الأسمدة الكيماو ية

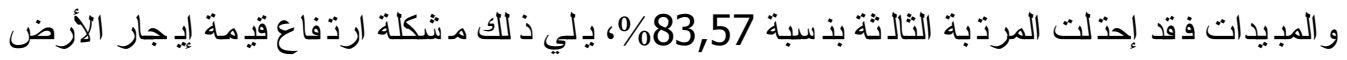

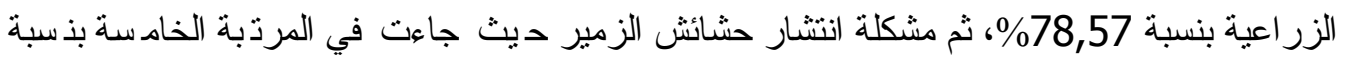

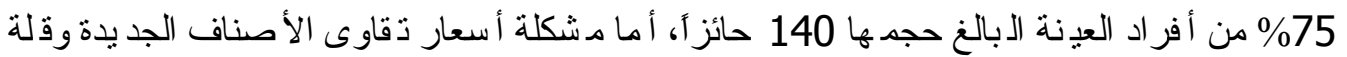

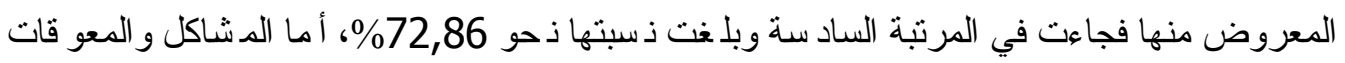

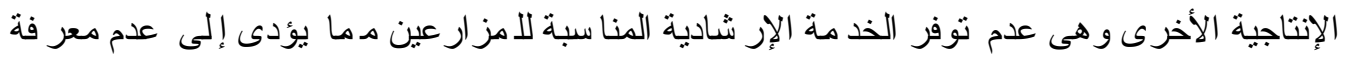

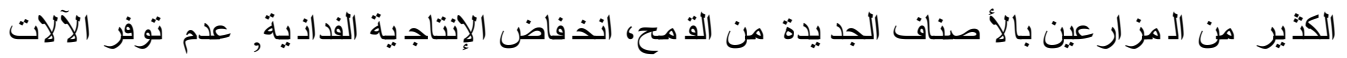

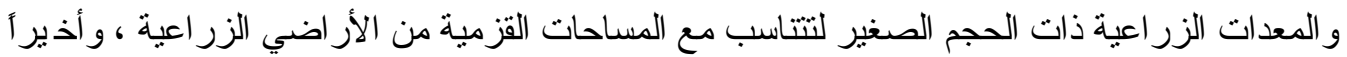

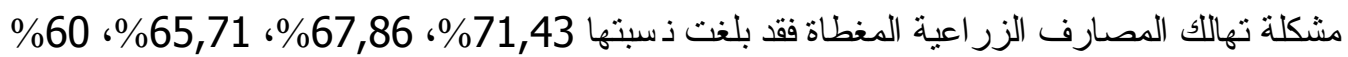
على التزتيب.

\section{(ب) المشاكل و المعوقات التسويقية}

و هى تلاك المشاكل التي تو اجه المزار عين أثناء تسويقهم للمحصول، و هذه الم شاكل ها مة ولـها

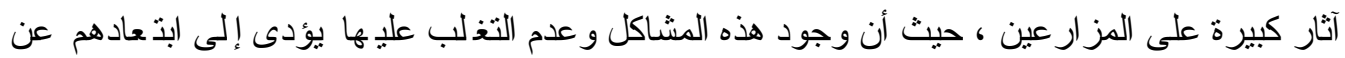

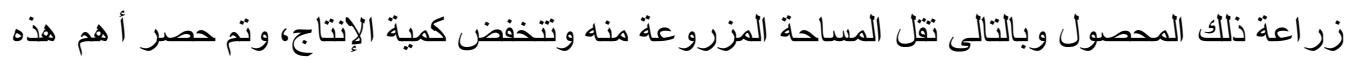

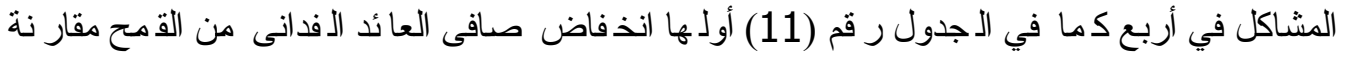

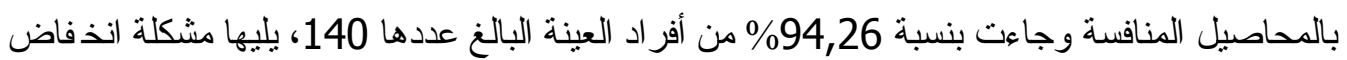
سعر أردب القمح بنسبة 88,57\% ، وجاءت مشكلة تسليم المحصول للجهات المعنبة في المرنبة الثالثة بنسبة 87,14\%، و أخير آ جاءت مشكلة تذبذب الأسعار وتحكم التجار في الأسو اق في المرتبة الر ابـعة 
جدول رقم (11) الأهمية النسبية لأهم المشاكل و المعوقات التي تواجه مزارعي محصول القمح بمحافظة الغربية وذلك من واقع عينة الار اسة الميدانية في

العام الزر اعي 2016 / 2017م.

\begin{tabular}{|c|c|c|c|}
\hline الأهمية النسبية & عدد & المشكلـــــة & \\
\hline إلمشكلة \% من إلعينة & 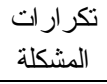 & 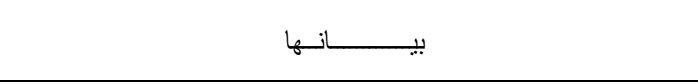 & أهميتها النسبية \\
\hline$\% 92,86$ & 130 & 1- ارتفاع أجور العمال الزر اعيين و عدم توفر هم وخاصة عند الحصاد & \multirow{10}{*}{ 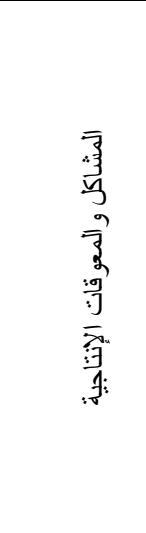 } \\
\hline$\% 87,14$ & 122 & 2- عدم تو افر المباه في التز ع و المساقي في أوقات كثيرة أثناء الموسم & \\
\hline$\% 83,57$ & 117 & 3- ارتفاع أسعار الأسمدة الكيماوية و المبيدات & \\
\hline$\% 78,57$ & 110 & 4- ارتفاع قيمة إيجار الأرض الزر اعية. & \\
\hline$\% 75$ & 105 & 5- انتشار حشائش الزمير & \\
\hline$\% 72,86$ & 102 & 6- ارتفاع أسعار نقاوي الأصناف الجديدة وقلة المعروض منها. & \\
\hline$\% 71,43$ & 100 & 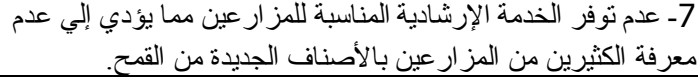 & \\
\hline$\% 67,86$ & 95 & 8- انخفاض الإنتاجية الفدانية & \\
\hline$\% 65,71$ & 92 & 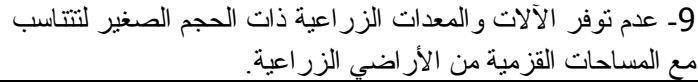 & \\
\hline$\% 60$ & 84 & 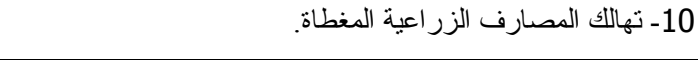 & \\
\hline$\% 94,26$ & 132 & 1- انخفاض صافي العائد الفداني مقارنة بالمحاصيل المناف سة بـسبب & \multirow{4}{*}{ 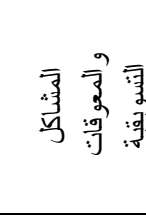 } \\
\hline$\% 88,57$ & 124 & 2-إنخفاض سعر أردب القمح & \\
\hline$\% 87,14$ & 122 & 3-صعوبة تسليم المحصول للجهات المعنية & \\
\hline$\% 85,71$ & 120 & 4ـ تذبذب الأسعار وتحكم التجار في الأسواق & \\
\hline
\end{tabular}

حيث أن : - 20 - n

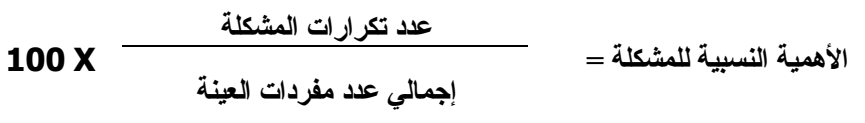

المصدر : بيانات استمار ات الاستبيان لعينة الدراسة الميدانية.

\section{التوصيات}

1. تشجيع المزارعين على عمل تجميعات زراعية وذلك للتغلب على مشكلة تفتت الحيازات الزر اعية، وذلك للإستفادة القصوى من الخدمات الزراعية, و التي من أهمها استخدام الآلات

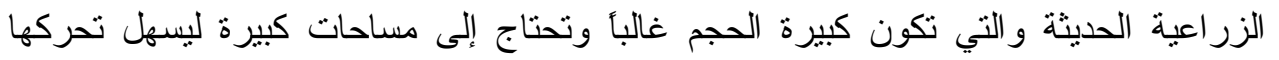
و الاستفادة منها وذللك لنطبيق مبدأ وفور ات السعة حيث تتخفض التهاع التهاليف بزيادة حجم الإنتاج.

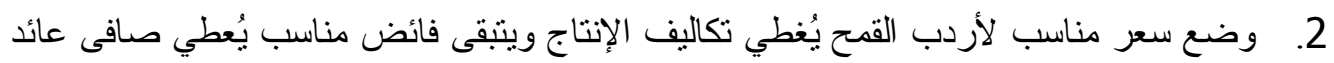
للمز ارع يشجعه على الاستمر ار في زر اعة المحصول و لا يتجه لزر اعة محاصيل أخر بي منافسة.

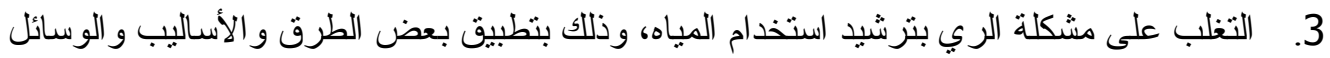
المساعدة على ذلك و التي من أهمها: • • تبطين الترع وقنوات الري وتتظيم عملية ورود الماء فيها لتقليل الفاقد من

$$
\text { المياه. }
$$

يجب تشجيع المز ارعين على استخدام آلات تسوية التربة بأثنعة الليزر .

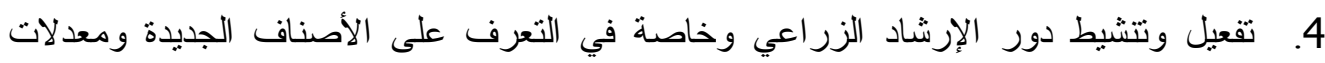

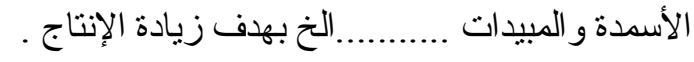


5 تسهيل إجر اءات تسليم المزارعين لإنتاجهم من محصول القمح للجهات المعنية وكذا سرعة

\section{(لماخص}

يتتاول هذا البحث الآثار الاقتصادية لتقتت حيازة الأراضي الزراعية على إنتاجية وعائد

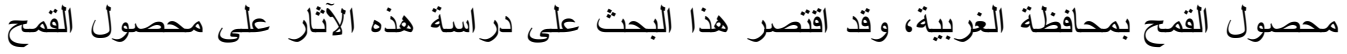
صنف جميزة 11 بمحافظة الغربية، حيث تم اختبار عينة حجمها 140 مز ارعأ تم توزيعها على ثلاث فئات حيازية، الأولي تضم المزارعين أصحاب الحيازات التي تبلغ مساحة كل منها أقل من فدان

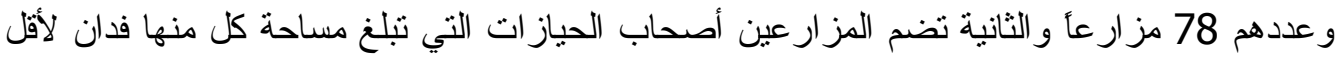

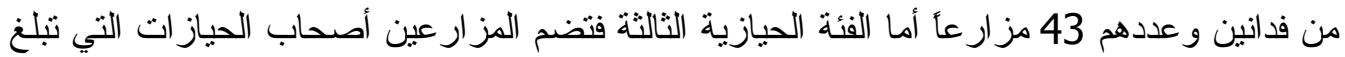
مساحة كل منها فدانين فأكثر و عددهم 19 مزار عأ وقد استهدفت الدراسة تقيبم تلك الفئات الحيازية للتوصل إلى معرفة أفضلها و التي تحقق أعلى معدلات من الجدارة الإنتاجية و الكفاءة الاقتصادية، حيث تم عمل مقارنة بين الفئات الحيازية الثناث وفقاً لبنود التكاليف الإنتاجية، وتبين من نتائج تحليل التباين وجود فرق معنوى عند مستوى0,01 بين الفئات الحيازية الثلاث في جميع بنود التكاليف الإنتاجية، حيث اتضح أن التكاليف الإنتاجية المتغيرة قد بلغت حو الي وني 4492، 3655، من الفئة الحيازية الأولي و الثانية و الثالثة على الترتيب، أي أن التكاليف الإنتاجية تتخفض قيمتها عند الانتقال من فئة حيازية صغيرة إلى فئة حيازية أكبر، ويرجع ذللك إلى مبدأ [وفورات السعة]، حيث تتخفض التكاليف بزيادة حجم الإنتاج، كما تم التعرف على على كميات عناصر الإنتاج اللازمة لإنهات لإنتاج الفدان

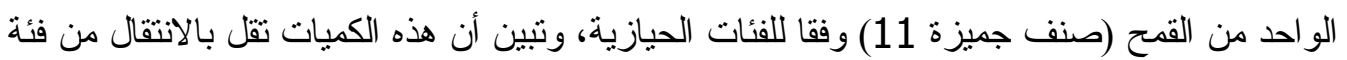
حيازية أقل إلى فئة حيازية أكبر ، وتبين من نتائج تحليل التباين أنه توجد فروق بين التين كميات هذه العناصر في كل من الفئات الأولي والثانية و الثالثة عند مسنوى 0,01، كما تم حساب المقاييس المطلقة و النسبية للكفاءة الاقتصادية لإنتاج الفدان من محصول القمح بالفئات الحيازية الثناث و أهم هذه المقاييس إجمالي

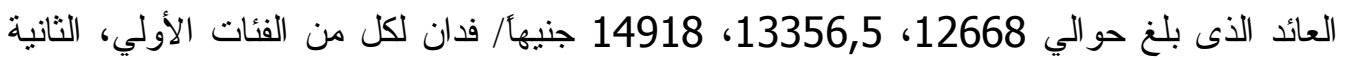

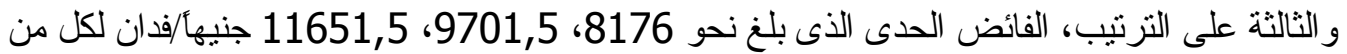
الفئات الأولي، الثانية و الثالثة على النرتيب، صافى العائد الذى بلغ حو الي 4135، 5701,5،

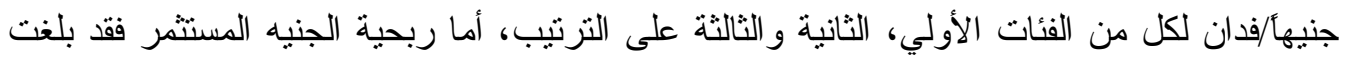
نحو 0,5، 0,74، 1,1جنيه/جنيه في كل من الفئات الأولي، الثانية والثالثة على الترنيب، أما معدل

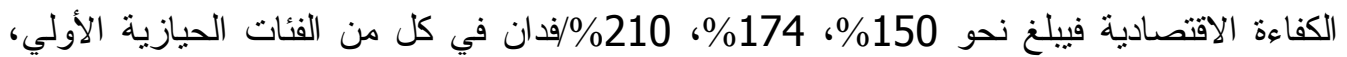
الثانية و الثالثة على الترتيب، و أثنارت نتائج تحليل التباين إلى وجود فروق معنوية كبيرة عند مستوى معنوية 0,01 بين المقاييس الاقتصادية السابق ذكرها في كل من الفئات الحيازية الأولي، الثانية و الثالثة

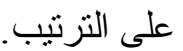

كما نم تقدير دو ال إنتاج محصول القمح (صنف جميزة 11) بكل من الفئات الحيازية الأولي، الثانية و الثالثة على الترتيب، و أثنارت بيانات هذه الدو ال أنها معنوية عند مستوى 0,01 استتادا إلى قيمة

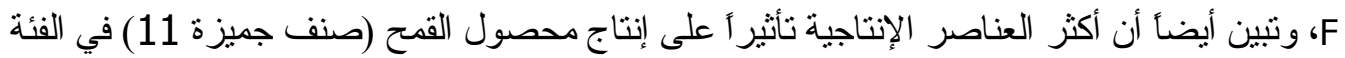
الأولي هي ماكينة الرى، الدر اس الآلي و التقاوى أما في الفئة الثانية فكانت أكثر العناصر الإنتاجية

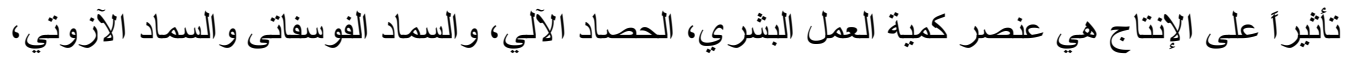

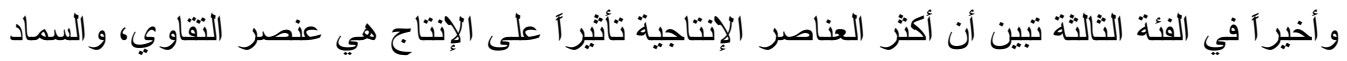

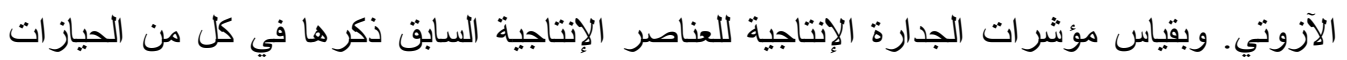


الثناث يتبين أن المرونة الإنتاجية الاجمالية للدالة المقدرة للفئة الأولي تبلغ نحو 0,995 ويشير ذلك إلى

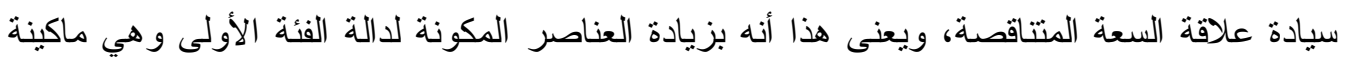

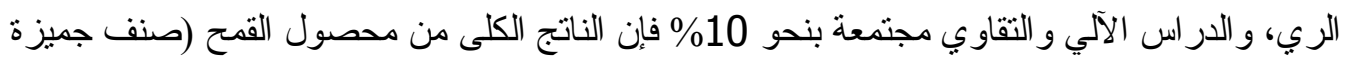
11) يزداد بنحو 9,95\%، كما ينتين أن مقدار المرونة الإنتاجية الاجمالية للدالة المقدرة للفئة الثانية الثانية

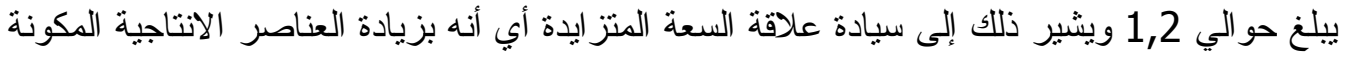

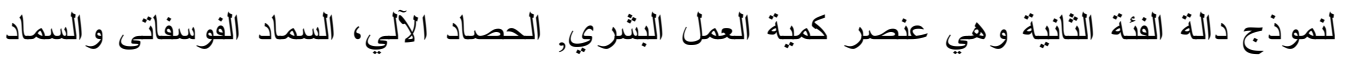

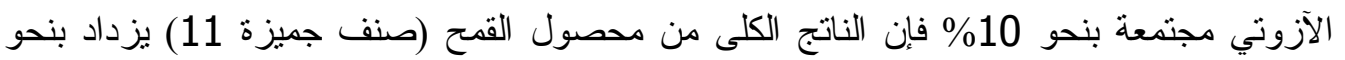
12\%، ويشير ذلك إلى سيادة علاقة السعة المتز ايدة وكذا نبين أن المرونة الإنتاجية الإجمالية للادالة

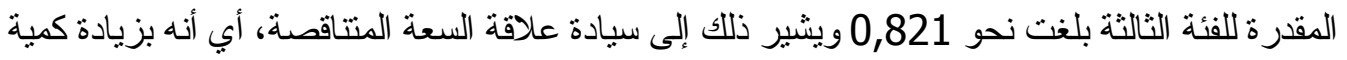

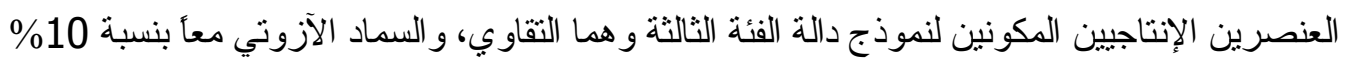
فإن كمية الناتج الكلى من محصول القمح (صنف جميزة 11) تزداد بنحو 8,21\%

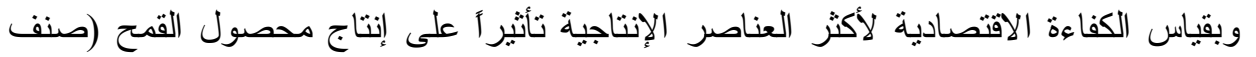

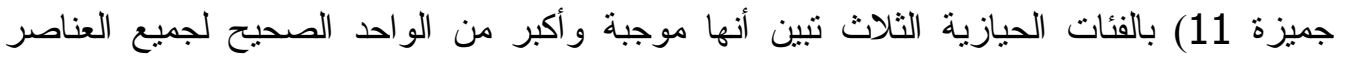

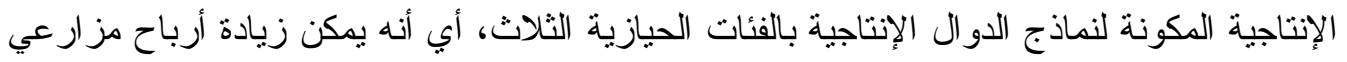

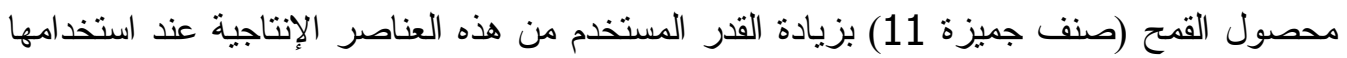
بالقدر الذى يحقق الكفاءة الاقتصادية, وتتحقق اقصي كفائه اقتصادية لاستخدام المورد الانتاجي عندما لإداد تكون قيمة الناتج الحدي للمو ارد نساوى نفقته البديلة.

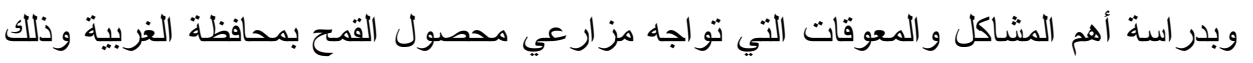

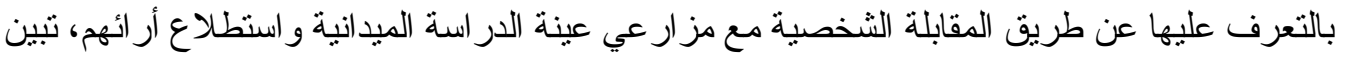

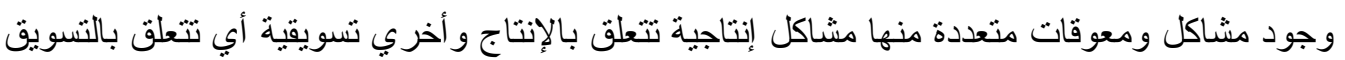

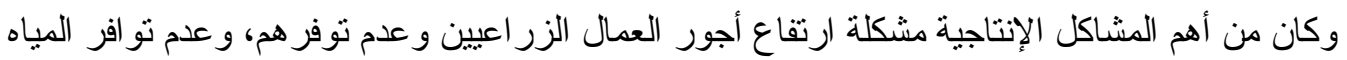

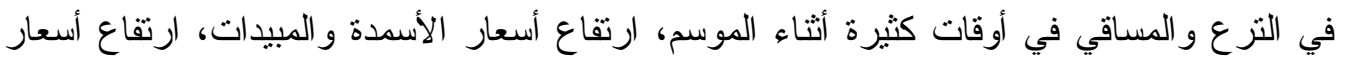
تقاوي الأصناف الجديدة، انخفاض الإنتاجية الفدانية وتهالك المصارف الزر اعية المغطاة، أما المشاكل التسويقية فتمنلت أهم هذه المشاكل في انخفاض صافي العائد الفدانى مقارنة بالمحاصيل المنافسة، انخفاض سعر اردب القمح، صعوبة تسليم المحصول للجهات المعنية و أخير أذبذب الفئ الأسعار وتحكم

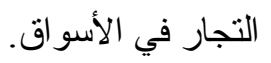

\section{المر اجع ومصادر البيانات}

1- الجهاز المركزي للتعبئة العامة و الإحصاء -نشرة الري و المو ارد المائية ـأعداد مختلفة.

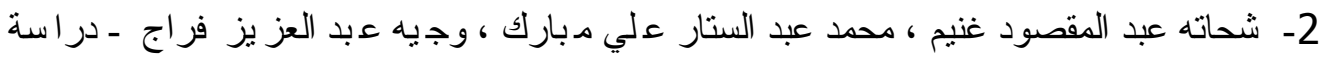

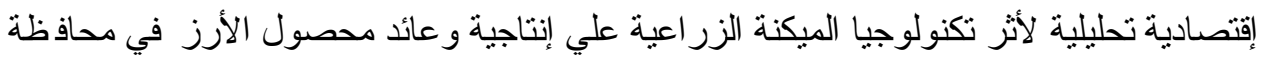

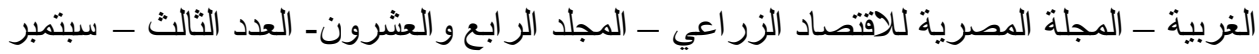

3- محمد عبد الستار علي مبارك ـ در اسة اقتصادية لإنتاج عـل النحل بمحافظة الغربية ـ المجلة

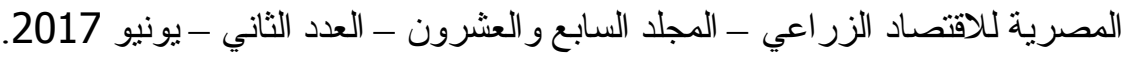

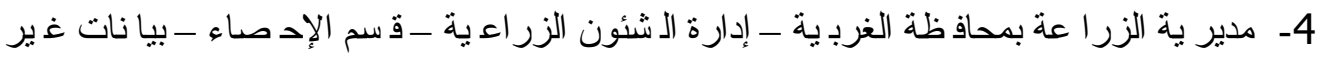


834 AN ECONOMIC EFFECTS OF THE FRAGMENTATION OF AGRICULTURAL LAND ON THE PRODUCTIVITY AND YIELD OF THE WHEAT CROP IN GHARBIA

5- مديرية الزر اعة بمحافظة الغربية ـ الإدارة الزر اعية بكلٍٍ من مر كزي زفني و المدله الكبري ـ سجلات حصر محصول القمح.

6- منظمة الأغذية و الزر اعة "الفاو ".

7- وز ارة التخطيط و المتابعة و الإصلاح الاداريـ قاعدة البيانات الإحصائية ـ على شبكة المعلو مات الدولية WWW.mop.gov.eg

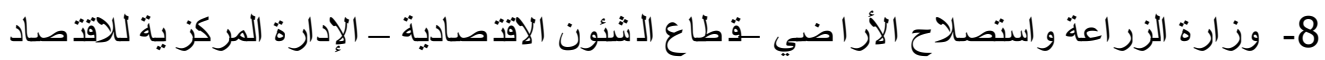
الزر اعي- النشرة السنوية للاقتصاد الزر اعي- أعداد مختلفة.

9- يوسف توفيق جرجس و اصف -در اسة تحليلية لدو ال إذتاج وذكاليف مدصول الق مح بمحافظة

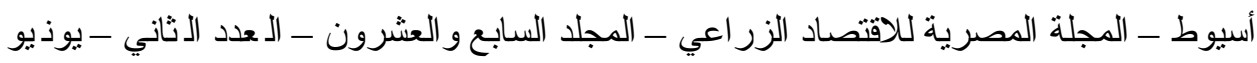
$2017(ب)$ 